\title{
EMPOWERING LEADERSHIP IN HOSPITALITY AND TOURISM MANAGEMENT: A SYSTEMATIC LITERATURE REVIEW
}

\begin{abstract}
Purpose - This article reviews the empirical studies on empowering leadership in hospitality and tourism and proposes an associated research agenda.

Design/methodology/approach - A disciplined selection process using transparent inclusion and exclusion criteria resulted in a final sample of 25 empirical studies. The research results from these studies were systematically analyzed using content analysis.

Findings - The synthesis of these articles highlights that: (a) studies on empowering leadership in hospitality and tourism are mainly based on motivational theories and theories with a social orientation; (b) empowering leadership has been examined within various cultures mostly using quantitative methods; (c) multiple instruments are used to measure empowering leadership; and (d) empowering leadership is a variously defined construct that has been found to promote creativity and innovation, service performance and various employee attitudes and behaviors.

Research limitations/implications - We provide an integrated framework for empowering leadership in hospitality and tourism contexts, proposing theoretical implications and directions for further research.
\end{abstract}

Practical implications - This review identified growing research interest in empowering leadership in diverse hospitality and tourism contexts as well as an increasing impetus to understand how leaders can effectively empower their subordinates.

Originality/value - The article provides a systematic understanding of empirical research examining the theoretical frameworks, antecedents, mediators, moderators and consequences of empowering leadership in various hospitality and tourism contexts. Significant opportunities remain for further research to address the gaps and limitations discovered.

Keywords: Empowering leadership, hospitality, tourism, systematic literature review

Paper type: Literature review 


\section{Introduction}

The hospitality and tourism industries have several unique characteristics that create greater challenges for workers in comparison to other industries. These are highly competitive service sectors facing increasing customer demands, which necessitate employees' creativity and a commitment to service quality improvements (Huertas-Valdivia et al., 2019; Lin et al., 2019), whilst simultaneously creating and delivering services (Zhou et al., 2018). In addition, hospitality and tourism are working environments characterized by precariousness and high uncertainty, in which workers suffer from occupational stress, unsupportive cultures, overload, and low pay (Kim and Agrusa, 2011; Zhou et al., 2018), leading to high rates of turnover and absenteeism (HuertasValdivia et al., 2019). These issues and challenges can be addressed by providing hospitality and tourism workers with autonomy and encouraging them to participate in decision making processes to proactively solve problems, create solutions, and find meaningfulness in their work, outcomes that have been associated with empowering leadership (Hassi, 2019; Zhang and Zhou, 2014). Contemporary hospitality and tourism organizations could apply empowering leadership, which has emerged as a positive leadership style (Lin et al., 2019), to address these challenges and achieve business success.

Empowering leadership can be defined as "leader behaviors directed at individuals or entire teams and consisting of delegating authority to employees, promoting their self-directed and autonomous decision making, coaching, sharing information, and asking for input" (Sharma and Kirkman, 2015, p. 194). Due to the ongoing flattening of contemporary hospitality and tourism organizations and the significance of teamwork, together with the role of employees as potential proactive players, empowering leadership offers a way forward to improve performance at individual, team and organizational levels (Arnold et al., 2000; Sharma and Kirkman, 2015). Distinct from other leadership styles such as servant leadership, transformational leadership, ethical leadership and charismatic leadership (Cheong et al., 2019), which also have positive effects on hospitality and tourism firm performance, empowering leadership particularly aligns with the trend toward employees having the autonomy to improve organizational processes related to their role (Srivastava et al., 2006). A number of larger hospitality and tourism corporations have implemented empowerment practices, for example, Ritz Carlton, The Four Seasons, and Carlson 
Rezidor, and have found that empowered employees tend to depart from regular duties and find creative solutions to resolve problems and satisfy customers (Huertas-Valdivia et al., 2019).

There has been a growth in empowering leadership research in the general management literature. This construct has received less but growing scholarly attention contextualized to hospitality and tourism (Fong and Snape, 2015; Tuckey et al., 2012). Despite this attention, a gap remains regarding the collation and integration of empowering leadership findings in hospitality and tourism through the conduct of a systematic literature review (SLR). Such a review is timely given the manageable number of existing studies and as the findings can further enhance academic and practitioner understanding in hospitality and tourism of the significance of empowering leadership for employee empowerment.

In a recent review of empowering leadership in the general management literature, Cheong et al. (2019) noted the overall conclusion of a prior meta-analytical study (Lee et al., 2018) and review (Sharma and Kirkman, 2015) that empowering leadership is a desirable leadership style in the management domain. Cheong et al.'s (2019) review of empowering leadership went beyond to unravel the multilevel issues of empowering leadership and its associated variables. Given the magnitude of the multifaceted nature of empowering leadership explored by Cheong et al. (2019), as well as in response to their recommendations for further investigations into contexts and theoretical lenses, we determined to conduct this SLR of empowering leadership in hospitality and tourism. Our purpose in doing so was to gain further insights into theoretical lenses informing the effectiveness of empowering leadership, multilevel issues, and associated constructs.

This SLR makes important contributions to the literature by reviewing the empirical studies on empowering leadership in hospitality and tourism and developing an integrated model that includes antecedents, moderators, mediators and outcomes of the construct. The SLR method was used to determine the scope and findings of the available empirical studies, and to appraise the measures, results, and influence of empowering leadership. To systematically organize and quantify the findings from the extant literature, we firstly discuss the emergence of empowering leadership in hospitality and tourism management. Then, we describe the SLR method. In the current SLR, we aim to address the following research questions relative to the extant hospitality and tourism literature: (1) How has empowering leadership been defined? (2) What theoretical 
perspectives have been adopted to study empowering leadership? (3) In which contexts has empowering leadership been empirically examined? (4) How has empowering leadership been investigated and measured? and (5) What are the antecedents, outcomes and mechanisms underlying the effects of empowering leadership? We conclude the paper by proposing a research agenda and practical implications.

\section{The emergence of empowering leadership research in hospitality and tourism management}

\subsection{The concept of empowering leadership}

From the 1980s onwards, organizations, including those in hospitality and tourism sectors, have flattened and decentralized and work roles have simultaneously involved higher levels of complexity and increased cognitive demands on workers (Humphrey et al., 2007). This changing work landscape has evolved in tandem with the emergence of empowering leadership (Pearce et al., 2003). The unique pressures on the hospitality and tourism sectors worldwide in 2020 has amplified the need for agility and innovation among the hospitality and tourism workforce (Baum et al., 2020). Employee empowerment occupies the central tenet of empowering leadership, which aims to encourage individual inspiration in the workplace through assigning duties and authority to the relevant organizational level (Conger and Kanungo, 1988).

Empowering leadership is a distinctive leadership style with unique characteristics which warrant its study as an independent construct (Cheong et al., 2019). Empowering leaders show confidence in the capabilities of their subordinates, highlight the importance of their work, enable them to engage in decision making and remove bureaucratic constraints on them (Ahearne et al., 2005; Zhang and Bartol, 2010). This leadership style has attracted recent scholarly attention in hospitality and tourism management (Cheong et al., 2019). As empowering leadership is suggested to affect creativity and innovation at individual, team and organizational levels, which in turn enhances firm performance, this leadership construct is considered an important driver of successful tourism and hospitality firms (Lin et al., 2019).

2.2. The advantages of empowering leadership in hospitality and tourism as compared to other leadership styles 
Prior studies have suggested that empowering leadership is a more effective leadership approach for hospitality and tourism industries compared to other leadership styles, including transformational leadership, servant leadership, participative leadership and directive leadership (Huertas-Valdivia et al., 2019). Lin et al. (2019) argued this impact was the case due to these sectors' unique characteristics, such as the transfer of power to employees so that they can quickly respond to customer demands and providing autonomy for them to find innovative solutions to customer complaints. In these settings, providing outstanding service requires autonomy for workers as they need to make quick decisions, particularly at the frontline level (Huertas-Valdivia et al., 2019). Sharma and Kirkman (2015) suggested that transformational leadership focuses on inspiring followers with higher goals but that this style does not emphasize independence and autonomy for followers. By contrast, empowering leaders transfer power to their subordinates so that they can respond quickly and effectively to customer and market demands.

Huertas-Valdivia et al. (2019) in studying Spanish hotel workers found that empowering leadership promoted psychological empowerment and job engagement while servant leadership did not. In comparison with participative leaders, Clark et al.'s (2009) study highlighted that leaders who empowered shaped a climate that transferred shared values to hotel frontline workers and enhanced their job satisfaction and commitment to service quality, while participative leadership was unrelated to these outcomes. Similarly, empirical findings from research on Vietnamese tourism small to medium enterprises (SMEs) reported that empowering leadership played an important role in developing a climate for innovation, which in turn promoted firms' innovation performance, while directive leadership, which focuses on adherence to rules and procedure, did not (Hoang et al., 2019). In summary, the literature reveals that empowering leadership is more efficacious for the hospitality and tourism contexts than other leadership styles. The mechanism for effectiveness is that empowering leadership provides autonomy and flexibility for subordinates, enabling them to effectively make prompt decisions and find innovative solutions in response to increasingly complex customer demands and dynamic business environments.

\section{Method}

A SLR was conducted to collate and integrate study findings on the topic of empowering leadership in hospitality and tourism.. The objective, replicable, systematic, and comprehensive 
nature of the method and its reporting process distinguishes it from traditional literature reviews (Klassen et al., 1998). Our systematic review rigorously followed the five-step framework for conducting SLRs proposed by Khan et al. (2003), which includes: framing questions for a review, identifying relevant work, assessing the quality of studies, summarizing the evidence, and interpreting the findings. The current SLR places an emphasis on research studies that have investigated the theory of empowering leadership and empirically studied salient concepts in hospitality and tourism management.

\subsection{Search methods}

In the process of conducting the SLR, comprehensive database searches were carried out with the aim of ensuring collation of as many relevant high quality studies as possible to address the research questions. Following the suggestion of Bavik (2020), Scopus and Web of Science databases were searched in a systematic manner based on the inclusion and exclusion criteria and the sample described in the following sections. These databases were used because they are considered two of the most inclusive databases available covering refereed journals in the social sciences (Crossan and Apaydin, 2010).

The criteria for articles selected for the initial search included that the study (a) be published in a peer-reviewed journal; (b) be written in the English language; and (c) use the keywords (“empowering leader" OR “empowering leadership”) AND (hospitality OR hotel OR tourism OR travel OR accommodation OR airlines OR event OR restaurant OR catering OR recreation OR casino OR cruise). The year of publication was not restricted in the search process but the cut-off date was end of January 2021. After articles containing the designated keywords were retrieved, they were examined to avoid any duplicates. The external duplicate numbers were recorded and then removed while keeping a running total of new articles.

As the next step, a second filter search was conducted to evaluate the eligibility of the articles against the inclusion criteria. The full text version of each article was retrieved for those studies that met three criteria. These were that the article: (a) be an empirical study; (b) discuss empowering leadership as the primary topic; and (c) investigate empowering leadership in a hospitality and tourism context. As the research objective was to gain an understanding of the empirical study of empowering leadership, research studies where the major focus was on building 
models or testing measurement scales were excluded from consideration. The absence of at least one of the inclusion criteria in the abstract, results and/or discussion sections of the study meant that the article was excluded from further consideration. Figure 1 presents a flowchart of the search process.

\section{Insert Figure 1 here}

\subsection{Sample}

Following the search process, 585 articles containing the identified keywords were initially sourced and then 240 were retained after the duplicates were removed. To ensure that only the studies meeting the requirements were included, we first screened all studies and excluded those that were either neither empirical studies nor published in peer-reviewed journals (i.e., conference proceedings). After this round, a total of 70 articles were retained for analysis. A second screening was conducted to exclude articles which did not examine empowering leadership as the main topical theme or did not use a data sample from the hospitality and tourism sectors. The assessment of full text articles narrowed the final sample to 25 empirical studies (as shown in Figure 1). The time span of accepted articles ranged from 2006 to 2021. The 25 articles were published in 13 journals in total, all of which used a quantitative method. Table 1 lists the source journals in the sample and the number of articles selected from each journal.

\subsection{Analysis}

Using content analysis, the research results from the empirical studies were categorized in two steps (Cummings et al., 2010). First, they were classified into categories based on their common attributes. Next, each thematic category was examined to determine definitions, theories, contexts, methods, and measures utilized in empowering leadership research. We then identified the antecedents, mediators, moderators and the outcomes of empowering leadership in the hospitality and tourism contexts (see Figure 2). A synthesis of the conclusions from articles were grouped according to emergent themes. To prevent bias, two independent researchers were involved in the coding process and another two researchers critically reviewed and compared the coding results.

\section{Insert Table 1 here}




\section{Findings}

The findings of the SLR with respect to each of the research questions are discussed in turn. The resulting empirical studies are summarized in Table 2.

\subsection{Defining empowering leadership in hospitality and tourism}

To answer research question 1, our SLR sought to identify an accepted definition of empowering leadership applied in hospitality and tourism studies and found a number of common words but no single commonly agreed definition. Amongst the definitions drawn from the empirical studies, the most frequently cited were those by Arnold et al. (2000) and Ahearne et al. (2005). Given the citations and endorsement of these two works, the ensuing discussion provides an analysis and integration of the concepts used.

The first key concept of empowering leadership is collaboration, which is facilitated by empowering leaders between employees and, as a result, power and decision-making duties are shared among team members (Arnold et al., 2000). In their study, Arnold et al. (2000) argued that the typical behavior of an empowering leader comprises the following five characteristics: leading by example, coaching, participative decision making, informing, and showing concern. Empowering leaders show confidence in the capabilities of their subordinates, highlight the importance of their work, enable them to engage in decision making and remove any bureaucratic constraints on them (Ahearne et al., 2005). This definition accentuates the actions of the leader, specifically in sharing authority or giving a higher sense of responsibility and stronger level of autonomy to employees.

Common behaviors of empowering leaders, according to these definitions, embrace the notion of creating conditions whereby employees can meaningfully engage in decisions and actions in their work and grow in capability. Such leaders do so through an approach that is considerate, has a coaching-orientation, provides role modelling, encourages the sharing of information and authority and the removal of bureaucratic barriers.

\subsection{Theories utilized in empowering leadership research in hospitality and tourism}


To address research question 2, the theories utilized in empowering leadership research in hospitality and tourism were examined. The first theory stream that commonly appeared was selfdetermination theory. Six empirical studies were based on this theory (Ryan and Deci, 2000), which clarifies the process of enhancing employees' psychological empowerment related outcomes through intrinsic motivation, skill development practices and employee enablement, thereby satisfying the three needs of autonomy, competence and relatedness. Informed by selfdetermination theory, hospitality and tourism studies have examined how empowering leaders encourage service performance (Aryee et al., 2019), in-role behavior and affiliative extra-role behavior (Raub and Robert, 2010), job engagement (Huertas-Valdivia et al., 2019), voice behavior, knowledge sharing (Chiang and Chen, 2020), employee creativity (Hon, 2012) and team creativity (Hon and Chan, 2012).

A second theoretical perspective employed to explain the influences of empowering leadership included social-based theories, such as social learning theory (Bandura, 1977), social comparison theory (Festinger, 1954), the socially embedded model (Spreitzer et al., 2005), and social exchange theory (Blau, 1964). These collective theories provide an important base for empowering leadership research as they describe how empowering leaders use social interactions to change their followers' mindset and behavior. For example, informed by social exchange theory, Lin et al. (2020) found a negative association between empowering leadership and employees' knowledge hiding and Aryee et al. (2019) used a socially embedded model to explain the contribution of empowering leadership to employees' service performance.

Conservation of resources (COR) is another theoretical perspective that has been employed to examine the influences of empowering leadership. The main tenets of the COR framework suggest that employees make effort to obtain, preserve and protect valued resources, for example, personal characteristics, objects and social support (Hobfoll, 1989). This framework has been applied to explicate the contributions of empowering leadership to psychological responses and behavioral intentions (Boukis et al., 2020), work engagement and the service sabotage efforts of frontline employees (Zhou et al., 2018).

While the above theories have investigated the outcomes of empowering leadership, predominantly they focus on positive effects and neglect negative consequences of this leadership 
style. To that end, there was only one study in our sample (Hoang et al., 2019) that examined the negative impact of empowering leadership on innovation performance through the lens of the 'toomuch-of-a-good-thing' theory (Pierce and Aguinis, 2013).

\subsection{Contexts for investigating empowering leadership}

To understand its contextualization in hospitality and tourism studies and address research question 3, we examined the range of settings in which empowering leadership had been the key study focus. Our results suggest that empowering leadership has been investigated across a range of different countries and diverse hospitality and tourism work settings. Of the 25 studies, 20 were situated relative to particular countries or territories, and a further five were cross-cultural studies. Overall, the role of empowering leadership in hospitality and tourism has been studied in China $(n=6)$, the US ( $n=4)$, Taiwan $(n=2)$, Spain $(n=2)$, Norway $(n=1)$, the Republic of Korea $(n=$ 1), Vietnam $(n=1)$, Indonesia $(n=1)$, Egypt $(n=1)$ and Morocco $(n=1)$. Among these contexts, China and the US were the most common source of research participants. The analysis also revealed that empowering leadership had been investigated in five hospitality and tourism settings: hotels $(\mathrm{n}=18)$, restaurants $(\mathrm{n}=2)$, travel agents $(\mathrm{n}=2)$, airlines $(\mathrm{n}=1)$, and a mix of hotel, restaurant, and other hospitality organizations $(n=2)$. Notably, empowering leadership was examined in a hotel setting in most studies reviewed.

\subsection{Methods and measures used to study empowering leadership}

Quantitative surveys were the main data collection method used to study empowerment in hospitality and tourism, accounting for all studies in our sample. Of these 25 studies, nine measures were used to assess empowering leadership, the two most popular being the Arnold et al. (2000) instrument - used in nine studies and the Ahearne et al. (2005) instrument - used in seven studies (see Table 2). This aligns with the prominence of these studies in defining empowering leadership in the hospitality and tourism field.

The scale developed and empirically validated by Arnold et al. (2000) includes 15 items representing five factors of empowering leadership behavior: leading by example, participative decision-making, coaching, informing, and showing concern (Cronbach's alpha ranged in the 2000 study from 0.89 to 0.94 for these factors). The Ahearne et al. (2005) instrument consists of 12 
items and four factors which include; enhancing the meaningfulness of the work, fostering participation in decision making, expressing confidence in high performance, and providing autonomy from bureaucratic constraints. The key difference among the two instruments and their measures is the focus on concern for and coaching of people according to Arnold's approach versus Ahearne's incorporation of confidence in performance and meaningfulness of work. Additional scale instruments included that of Srivastava et al. (2006), which was examined in two studies and the measures developed by Cook (1981), Konczak et al. (2000), Manz and Sims Jr (1987), Babakus et al. (2003), Boukis et al. (2020), Martin et al. (2012), and Vecchio et al. (2010), which were each used in one study in our sample (see Table 2).

In answering research question 4, our SLR found that nine measures were tested in 25 quantitative studies, with Ahearne et al.'s (2005) and Arnold et al.'s (2000) achieving greater prominence in the literature but neither dominating. Each measure was developed based on definitions of empowering leadership discussed in the previous section. All the scales' coefficient alpha reliability estimates were above 0.85 , indicating they are reliable measures of the construct. Based on the preponderance of quantitative studies, there is a substantial opportunity to conduct qualitative studies of empowering leadership to describe the enablers, meaning and enactment of this leadership style across hospitality and tourism contexts and relationships. Next, we present the antecedents, outcomes and mechanisms triggering the effects of empowering leadership to address research question 5 .

\subsection{Antecedents of empowering leadership}

Eva et al. (2019) suggested a number of antecedents of leadership, such as team and organizational culture, climate, management at higher levels, and the characteristics of the leader. However, in our sample, there were only three studies that examined the antecedents of empowering leadership in hospitality and tourism contexts. The study by Elsetouhi et al. (2018) demonstrated that perceived leader behavioral integrity promoted empowering leadership behaviors, as such leaders who have integrity tend to coach their subordinates to be confident, motivate them to join in decision making processes and inform them about the meaningfulness of their assigned tasks. Additionally, Clark et al. (2009) reported that managers who are committed to service quality are likely to show an empowering leadership approach, based on a sample of 56 
customer-contact employees and 236 managers working in 199 American hotels. Furthermore, the findings of Huertas-Valdivia et al. (2018) demonstrated that managers who work in companies that implement high performance work practices tend to demonstrate an empowering leadership style. Combining the limited evidence from our sample, we suggest that empowering leadership behavior is influenced by both individual and contextual factors.

\subsection{Outcomes of empowering leadership}

\section{Creativity and innovation}

The impact of empowering leadership on creativity and innovation was highlighted in the results of eight of the 25 empirical studies. Empowering leadership has been credited with stimulating creativity and autonomy leading to improved team performance and innovation outcomes. The significance of empowering leadership in hospitality and tourism was investigated at individual, group and firm levels.

Similar results regarding a positive relationship between empowering leadership and creativity were found at both individual and team levels. Empowering leadership focuses on leader behaviors related to goal orientation and encouraging initiative and motivates the potential of employees. This leadership style substantially provides motivational support, stimulates creative self-efficacy, affects autonomous motivation, and promotes employee self-concordance, which are vital antecedents of employee creativity (Amabile, 1983) and employees' innovative behavior. At the team level, empowering leadership was associated with team creativity under the condition of high team task interdependence (Hon and Chan, 2012). This relationship was mediated by team creative efficacy, which arises when team members believe in a team's creative ability, and team self-concordance, which occurs when team members find their tasks meaningful or enjoyable (Hon, 2011; Hon and Chan, 2012).

Studies have found contradictory outcomes of empowering leadership on organizational innovation in hospitality and tourism firms. Hassi (2019) used a sample of 127 Moroccan hotels and found that empowering leadership positively influenced management innovation enabled by a climate for creativity. Similarly, empowering leadership had direct positive associations with product, process and administrative innovations in European and American hospitality 
organizations (Lim and Gon, 2021). However, a two-sided view of the relationship between empowering leadership and work performance has emerged suggesting evidence is mixed. For example, research has shown teams initially led by a directive leader perform better than teams led by empowering leaders, although subsequently, teams led by empowering leaders achieved better outcomes (Lorinkova et al., 2013). Empowering leadership was found to negatively influence the innovation performance of 37 SMEs in Vietnam (Hoang et al., 2019). In short, empowering leadership has potential to affect creativity and innovation in hospitality and tourism contexts.

\section{Service performance}

The influence of empowering leadership on service performance was investigated in six empirical studies in our sample. The findings demonstrated that the leadership style promoted thriving at work (Aryee et al., 2019) and job commitment (Clark et al., 2009), built psychological contract fulfilment (Wu and Chen, 2015) and shared values (Clark et al., 2009), and improved employees' psychological ownership (Lin et al., 2019). These factors were found to have mediating roles in the positive association between empowering leadership and service performance of employees working in restaurants, hotel, airline and tourism firms. Zhou et al. (2018) also identified that empowering leadership enhanced work engagement and reduced employees' service sabotage.

At the team level, empowering leadership was found to have an indirect and positive effect on team service performance as a result of the aggregated influence of team efficacy among team members (Srivastava et al., 2006). This finding supports previous research that emphasizes the significance of geographic dispersion applied to empowering leadership (Arnold et al., 2000; Hill and Bartol, 2016). The collective results of the studies reviewed suggest that empowering leadership paves the way for knowledge sharing and improves team cohesion, leading to improved service performance.

\section{Employee attitudes and behaviors}

The findings from 13 studies demonstrated that empowering leadership was associated with at least one specific employee attitude or behavior. Chiang and Chen (2020) endorsed the value of empowerment by showing that leaders, who encouraged greater autonomy and developed 
a cooperative climate, enabled their subordinates to express their opinions to supervisors and share knowledge with their coworkers. These observations align with studies that demonstrate a positive relationship between empowering leadership and job engagement (Huertas-Valdivia et al., 2018; Zhou et al., 2018). Empowering leadership may also affect employees' in-role behavior and affiliative extra-role behavior through the pathway of increased psychological empowerment (Raub and Robert, 2010). Similarly, through psychological empowerment, a number of other factors were implicated such as knowledge sharing (Tung and Chang, 2011), service-oriented behavior (Lin et al., 2019), and commitment to service quality (Clark et al., 2009; Hong et al., 2016). In addition, empirical evidence revealed that empowering leadership had a positive effect on hospitality and tourism employees in allowing them to voice their concerns (Chiang and Chen, 2020; Elsetouhi et al., 2018). In sum, the findings suggest that the enacting of empowering leadership has the potential to influence a range of employees' attitudes and behaviors in hospitality and tourism contexts.

\subsection{Mediators}

\section{Individual level}

Psychological empowerment, which refers to a personal experience of employees' intrinsic motivation based on cognitions about themselves in relation to their responsibility in the organization (Spreitzer, 1995), can be linked to leadership empowerment considering conceptual similarities. Psychological empowerment was considered an important empowering characteristic among subordinates, which had the potential to mediate the effect of empowering leadership on subordinate creativity and work performance (Zhang and Bartol, 2010). Given that empowering leadership can improve how employees experience intrinsic motivation in respect of their cognitions of competence, self-determination, impact and meaning (Fong and Snape, 2015), it is likely that psychological empowerment plays a mediating role in these associations. Raub and Robert (2010) conducted a survey on 541 employee-leader dyads from a multinational hotel chain and concluded that empowering leadership had a significant effect on psychological empowerment, which in turn positively affected both employees' in-role behavior and affiliative extra-role behavior. Furthermore, empirical evidence from Spanish hotels and American restaurant chains demonstrated that psychological empowerment mediated the associations between 
empowering leadership and job engagement and empowering leadership and organizational commitment (Huertas-Valdivia et al., 2019; Namasivayam et al., 2014).

The intervening role of knowledge sharing on the relationships between empowering leadership and its outcomes was also examined (Chiang and Chen, 2020). For example, Wu and Chen (2015) found that empowering leadership had a positive relationship with psychological contract fulfilment and knowledge exchange, which in turn were positively related to service performance based on data collected from 28 Taiwanese hotels.

\section{Team and organizational levels}

The mediating role of climate on the relationships between empowering leadership and its outcomes was examined in four empirical studies in the sample. Hunter et al. (2007) identified that climate is a domain referenced phenomenon that is specific to a context. In support of this idea, Schneider et al. (2013) argued that the concept of climate should be studied in a defining context. In past decades, scholars have examined a number of specific domain climates, for instance, climate for innovation (Amabile, 1996; West, 1990), safety climate (Zohar and Luria, 2005) and initiative climate (Raub and Liao, 2012).

Hassi (2019) identified that climate for creativity is a clear mediator for the association between empowering leadership and management innovation in Moroccan hotels. In line with this finding, evidence from Vietnamese tourism SMEs also confirmed that a climate for innovation intervened the association between empowering leadership and innovation performance (Hoang et al., 2019). Based on a survey of Taiwanese hotels, Chiang and Chen (2020) suggest that empowering leadership develops a cooperative climate that promotes job autonomy and enables employees to voice their opinions to leaders and motivates knowledge sharing among team members. In addition, initiative climate was found to be a clear mediator of empowering leadership. Specifically, the results of a survey of an European hotel chain by Hong et al. (2016) revealed that empowering leadership was related to a climate which encourages initiative, which in turn predicts personal initiative. In addition, empowering leadership promoted team knowledge sharing and team efficacy, and both concepts, in turn, predicted team performance (Srivastava et al., 2006). Based on a sample of 102 medium sized hotels in the US, knowledge sharing at team level was also reported to enable the influence of empowering leadership and team performance. 
Managerial empowering behaviors motivate the development of a team climate in which the sharing of knowledge is strengthened.

\subsection{Moderators}

There were five studies in our sample that investigated the moderating role of variables on the associations between empowering leadership and its outcomes. At the individual level, customer orientation was identified to moderate the effect of empowering leadership on thriving at work (Aryee et al., 2019). Furthermore, self-efficacy strengthened the empowering leadership work engagement relationship and the indirect relationship of this leadership style on service sabotage through work engagement (Zhou et al., 2018). Power values were found to moderate the effects of empowering leadership on employee behaviors, including in-role behavior, affiliative extra-role behavior and challenging extra-role behavior (Raub and Robert, 2010). At team level, team task independence increased the effects of empowering leadership on both self-concordance and creative efficacy at the team level (Hon and Chan, 2012). At the organizational level, studies supported that shared organizational social exchange moderated the effect of empowering leadership on service performance, whereas initiative enhancing Human Resource Management (HRM) systems were found to moderate the link between empowering leadership and initiative climate (Hong et al., 2016).

\section{Discussion}

\subsection{Integrated framework}

This SLR sought to collate and summarize extant peer reviewed literature on empowering leadership and synthesize the findings of the empirical studies to highlight associations among empowering leadership and its various antecedents, outcomes, mediating and moderating relationships. Based on this work, we offer a nomological network (shown in Figure 3) that aggregates the key empirical findings with respect to empowering leadership and its associations in a range of hospitality and tourism contexts.

\section{Insert Figure 3 here}

\subsection{Future research agenda}


Five crucial research agendas related to the study of empowering leadership in the hospitality and tourism were identified: (1) theoretical lens through which the effects of empowering leadership have been explained; (2) levels of analysis and multilevel issues in empowering leadership; (3) associated variables and underlying mechanisms of empowering leadership; (4) research design; and (5) study contexts.

\section{Theoretical advancement}

In terms of theories used to cast light on the effectiveness of empowering leadership, most studies have drawn on self-determination theory (six studies), social exchange theory (three studies), and the COR theory (two studies). However, research has begun to extend beyond examining the work-related outcomes of empowering leadership to focus on antecedents, impact of empowering leadership on managers, and contingencies. Hence, expanding the nomological network linked with empowering leadership may require the extended use of these theories as well as the application of other theories - new or existing and yet to be used as lenses to study empowering leadership. First, beyond its merit in explaining the effects of empowering leadership, self-determination theory could be usefully applied to understand those contextual factors and individual attributes that contribute to managers' autonomy on how to lead, competence to lead, and relatedness to others.

Second, the two tenets of the COR theory, namely resource investment for resource gain spirals and resource caravan pathways (Hobfoll, 1989), could be employed to explain not only the effects and boundary conditions of empowering leadership but also its antecedents. Resources from contextual sources (e.g., HRM, organizational culture) or resources accrued through practicing empowering leadership (e.g., self-actualization, self-esteem) may buffer potential resource loss from power sharing and drive leaders to invest in empowering employees. Additionally, the resource investment tenet can elucidate how empowering leadership, which represents a source of resources, stimulates employee's accrual of resources to develop particular behaviors and contribute to team and/or organizational outcomes. Resource caravan pathways can explicate how empowering leadership co-travels and mutually interacts with other resources (e.g., situational resources) to shape behaviors among employees. 
Third, future research could apply situational strength theory (Meyer et al., 2010) to address the lack of individual and contextual boundary conditions in the empowering leadership literature. This theory could surface moderators of empowering leadership as well as juxtapose empowering leadership with other leadership approaches (e.g., authentic, responsible leadership) to strengthen its effectiveness in hospitality and tourism firms (Wang and Xie, 2020).

Fourth, in this review, hospitality and tourism studies have predominantly focused on empowering leadership as a single leadership style. To bridge this gap, future research should adopt paradoxical leadership theory (Cunha et al., 2019) to unravel the synchronic or balanced pursuit of empowering leadership with an opposing leadership style such as directive or authoritarian leadership (Hunter et al., 2017), as well as the effects of this integrated leadership on work-related outcomes.

\section{Levels of analysis of empowering leadership}

The review reveals that most empowering leadership studies in the hospitality and tourism domain have been conducted at the individual and group levels. Little scholarly attention has been paid to the study of empowering leadership at multiple levels, dyadic, or the organizational level and addressing this gap is a crucial extension of empowering leadership research.

At the individual level, the psychological perspective of empowering leadership has dominated, with more focus on psychological outcomes such as psychological empowerment, job autonomy, psychological ownership, psychological contract fulfilment, self-concordance, selfefficacy, and job satisfaction. Though research on empowering leadership at the individual level has delved into several employee outcomes (e.g., service performance, in-role behavior, extra-role behavior, service innovative behavior) (Aryee et al., 2019; Raub and Robert, 2010), more economic and social outcomes, such as productivity improvements, customer-oriented organizational citizenship behavior, or eco-friendly behavior could be investigated in future research.

Assessing empowering leadership at the dyad level will advance our understandings of this leadership style through a multilevel lens. An extension to the current literature might examine empowering leadership at the dyad level (Vecchio et al., 2010), such as how temporal dynamics 
of dyadic relationships between leaders and followers influence the temporal variance in employee empowerment. Associated individual outcomes of this process (e.g., employee in-role/extra-role behaviors and performance) as well as mediation mechanisms (e.g., leader-follower empowerment expectation-behavior match) and boundary conditions underlying the process (e.g., employee regulatory focus or role identity) should be unpacked as well. Process-oriented perspectives such as relational leadership theory may be employed to shed light on such leader-follower dyadic relationships.

Additionally, future research should investigate empowering leadership at the firm level such as the effects of CEOs' empowering leadership of organizations and its contributions to organizational outcomes such as organizational performance, innovation, and sustainability, through collective phenomena such as organizational learning, developmental culture, collective decision making, and/or collective job crafting (Carmeli et al., 2011; Ling et al., 2015). Feasible boundary conditions for the effects of organization-level empowering leadership should also be identified and tested, including boundary conditions within the organization (e.g., organizational culture or climate, social capital, or HRM practices and strength) and outside the organization (e.g., external involvement). Moreover, articulation of theoretical justifications for the effects of empowering leadership at the organizational level, such as the dynamic capabilities perspective, will contribute new understanding of comparative firm performance especially in mergers and acquisitions.

Associated constructs of empowering leadership

This SLR revealed limited research, and therefore limited understanding of, the individual and contextual factors that predict empowering leadership in the hospitality and tourism field and that may constrain interventions to enhance empowering leadership. This gap should be urgently addressed. Due to the theoretical and empirical associations of the Big Five personality traits (Costa Jr and McCrae, 2008) and other personality factors such as altruism and humility with some leadership styles, such as servant and transformational leadership (Chon and Zoltan, 2019; Gui et al., 2020; Hunter et al., 2013), future research may seek to examine which individual differences may activate or inhibit empowering leadership among managers. Future studies could also examine if the "Dark Triad" personality traits (Paulhus and Williams, 2002), including narcissism, 
Machiavellianism and psychopathy, affect the development of empowering leadership in hospitality and tourism organizations.

Since scholars have reported the integration of strategy and managerial practices in shaping leadership (Do et al., 2018), the field should encourage studies to go beyond the current focus on HRM practices and capture the interactions between strategy combined with HRM practices as a contextual antecedent to empowering leadership. In addition to studying individual or contextual antecedents of empowering leadership in isolation, researchers can adopt the person-situation interactionist theory (Schneider, 1982) to investigate if individual factors (e.g., personality traits), contextual factors (e.g., HRM) and follower-based factors work in concert to predict empowering leadership among hospitality and tourism managers.

While the review indicates that mediation mechanisms have been examined at individual, team, and organizational levels, a gap remains in understanding the mediating role of the empowerment of co-worker group or lower-level managers. Since leaders may influence employees indirectly through affecting their co-worker group (Gill and Caza, 2018), insights into group-based effects of empowering leaders through empowering co-workers would extend current knowledge. Future studies should also adopt the trickle-down effect perspective (Byun et al., 2020) to unfold how empowering leadership cascades from higher-level managers, through lower-level managers, to employees.

Research to explore mechanisms that underline the mixed results with regard to the effectiveness of empowering leadership in hospitality and tourism organizations are a further fruitful avenue for deepening understanding. For instance, Hassi (2019) identified that empowering leadership positively influenced management innovation via a climate for creativity and Lim and Gon (2021) reported that empowering leadership had direct positive associations with product, process and administrative innovations. Empowering leadership, however, was found to negatively influence the innovation performance of 37 Vietnamese tourism SMEs (Hoang et al., 2019). Since Cheong et al. (2016) indicated that empowering leadership promoted self-efficacy and the work performance of subordinates, while some specific empowering behaviors negatively affected the work outcomes of followers by increasing job tensions, future research should explore 
whether self-efficacy and job tensions are two mediation mechanisms that can explain the contradictory contributions of empowering leadership to innovation.

The review also indicates limited understanding of boundary conditions under which empowering leadership is effective. Boundary conditions in this review are confined to employee self-efficacy, customer orientation, team task interdependence, and initiative enhancing HRM systems. Future research efforts should bridge this gap by investigating how empowering leadership and different level factors operate in concert to shape work outcomes. Specifically, studies should consider individual contingent conditions such as subordinates' demographic characteristics (e.g., gender, age), psychological characteristics (e.g., personality traits, locus of control) and social characteristics (e.g., education, occupation, employment status). Studies which examine situations under which empowering leadership is possible are needed, including situational factors within (e.g., organizational culture, justice, politics) and beyond the organization (such as type of industry sector, customer behaviors, national culture).

\section{Research design}

All studies in our review adopted a quantitative design based on survey data collection methods. To address this design limitation, dedicated qualitative research designs, as well as mixed methods designs enabling triangulation, should be adopted to examine how leader-member dyad relationships yield variances in employee empowerment over time. Furthermore, the review revealed a focus on cross-sectional design among the empowering leadership studies, which offers limited understanding of causal relationships between empowering leadership and work-related outcomes. In future studies, such causal inferences could be derived from longitudinal designs, cross-lagged designs, cohort studies or field experiments. Field experiments can also provide evidence of how empowering leaders are developed. Researchers could collaborate with hospitality and tourism organizations to provide training workshops on empowering leadership to measure how such interventions promote empowering leadership behaviors among managers in experimental compared to control groups and translate these insights into practice.

\section{Study contexts}


The majority of the studies had samples drawn from hospitality organizations based in the US and China. Though culture may affect empowering leadership (Cheong et al., 2019), those studies did not investigated culture as a potential boundary condition for the effectiveness of empowering leadership. Among cultural values, collectivism and power distance may influence employee responsiveness to empowering leaders (Cheong et al., 2019). In Asian collectivistic countries (Khosrowjerdi et al., 2020), since employees tend to be obligated to, as well as desirous of pleasing leaders, they may feel more pressure and less responsiveness to empowerment from leaders in comparison to their counterparts in countries characterized by individualism (e.g., the US, Canada, the UK, Australia) (House et al., 2004).

In countries with high power distance such as China, Indonesia, Malaysia, and Vietnam (Khosrowjerdi et al., 2020), followers may also consider leaders as holding deep-rooted status, power, and superiority (Kirkman et al., 2009), which may constrain leader-follower exchanges (Botero and Van Dyne, 2009) and give rise to follower reluctance to approach leaders (Kirkman et al., 2009). Contrarily, in countries with low power distance (e.g., the US, Canada, the UK, Australia) (Khosrowjerdi et al., 2020), employees are inclined to deem leaders to be approachable (Botero and Van Dyne, 2009) and hence more responsive to leader empowerment. Therefore, future studies should diversify study contexts by engaging samples from different cultures including developed and developing countries, and identifying divergences in the effectiveness of empowering leadership across cultural contexts. In addition, since the review indicates a focus on the hotel context, future research should enhance the generalizability of empowering leadership studies across hospitality and tourism contexts such as resorts, casinos, restaurants, retail, airlines, transport and tour operators.

Another extension to present studies in the hospitality and tourism domain may entail exploring the effectiveness of empowering leadership during crises (Zhang et al., 2020). This is crucial since hospitality and tourism is one of the industries severely affected by crises such as disasters (e.g., tsunamis, earthquakes) and pandemics (e.g., SARS, COVID-19) (Baum et al., 2020; Lim and To, 2021). During a crisis, employees in the workplace tend to prefer high support to high empowerment (Birkeland et al., 2017), which represents a burdening process (Cheong et al., 2016). On the contrary, employees who work from home tend to benefit from empowering leadership, especially when working from home is a response to an external threat (such as COVID-19) 
(Stoker et al., 2021). Therefore, the contributions of empowering leadership to hospitality and tourism employees' wellbeing, resilience, and performance in times of crises should be investigated to enhance understanding of how to exert empowering leadership effectively.

\subsection{Practical implications}

Considering the significance of empowering leadership in hospitality and tourism settings in addition to a growing need to understand how leaders can effectively empower their employees, our SLR provides important managerial implications for hospitality and tourism practitioners. First, this review highlights the role of empowering leaders in achieving desirable outcomes at individual, team and organizational levels. Therefore, hospitality and tourism organizations should focus more on building empowering leadership for managers at all levels to improve these outcomes. One way to do so is to recruit and select supervisors who lead by example, share power with their employees, provide autonomy, show confidence in their subordinates and encourage frequent communication at work. Furthermore, hospitality and tourism organizations are recommended to provide relevant leadership training and advancement programs for managers at all levels (Zhou et al., 2018) so that they recognize the significance of empowering leadership and practice the necessary skills to empower their subordinates.

Second, our SLR reveals the importance of mechanisms which link empowering leadership with positive outcomes. Hence, hospitality and tourism organizations should enact these mediators, for example, psychological empowerment, knowledge sharing, team and organizational climate, to maximize the effectiveness of empowering leadership. To attain this goal, empowering leaders ideally should maintain good communications with their employees to enhance their psychological empowerment (Lorinkova and Perry, 2017). In addition, we encourage hospitality and tourism policy leaders to disseminate supportive and enabling mechanisms through funding and other guidelines so that empowering leadership can reinforce the psychological empowerment of employees. On the other hand, empowering leaders must not only provide autonomy and creativity for followers but also support them with structure to handle difficulties and share knowledge when completing complex tasks (Luu, 2021). In addition, top level managers who focus on developing a climate that promotes innovation, cooperation and initiation will accrue 
benefits as these types of climates were found to be effective mediators of empowering leadership and its outcomes.

The current study emphasizes that the implementation of empowering leadership is complicated and involves much effort from organizational management (Lee et al., 2018). Therefore, a third implication concerns the boundary conditions that have been identified in this review. To survive and thrive in a competitive sector like hospitality and tourism, organizations need to provide appropriate training for team leaders and members so they can understand the importance of team task interdependence, individual and team efficacy. An initiating enhancing HRM system should be developed to strengthen the association between empowering leadership and initiative climate at the organizational level (Hoang et al., 2020).

\subsection{Limitations}

While this SLR was robustly conducted, it has some limitations. First, the search process was limited to indexed journals in Web of Science and Scopus databases, which were peerreviewed in the English language. This SLR cannot claim to cover non-indexed journals or dissertations since they did not meet our predefined inclusion criteria. With broad interest in empowering leadership, there are possibly more empirical studies carried out in other languages that can confirm, clarify and/or dispute the current findings.

In addition, our SLR integrated the findings of previous empirical studies. Therefore, this review did not include conceptual papers. We suggest that future reviews of empowering leadership could include conceptual papers in their selection criteria to contribute more to theorizing and model development of empowering leadership in hospitality and tourism management.

Finally, to guide future scholars when conducting SLRs, there are a number of aspects worthy of attention in terms of the quality of empirical research in the hospitality and tourism field. As SLRs first emerged from the medical field, where formulaic controlled trial studies are often carried out, critical appraisal tools can be applied to the research methods and research protocols reported to ensure consistency (Cook et al., 1997). Therefore, a comprehensive meta-analysis would be useful for further validation of the construct of empowering leadership and its 
antecedents and outcomes to tease out the precise quantum of impact of empowering leaders in hospitality and tourism industries (Lee et al., 2018).

\section{Conclusion}

In addressing the research questions, the findings of this comprehensive review sought to improve understanding empowering leadership behaviors in hospitality and tourism management, show the diversity of cultures, contexts, and research foci in which empowering leadership has been investigated, and identify instruments that have been used to measure this leadership construct. The review provides a systematic understanding of empirical research examining the theoretical frameworks, antecedents, mediators, moderators and consequences of empowering leadership in various hospitality and tourism contexts. Significant opportunities remain for further research to address the gaps and limitations noted in this paper. To conclude, we provide an integrated framework for empowering leadership in hospitality and tourism contexts, proposing theoretical and managerial implications and directions for further research.

\section{Acknowledgement}

The authors would like to thank the editorial board of the International Journal of Contemporary Hospitality Management and six anonymous reviewers for their insightful comments to help improve the quality of the article. We confirm that this article is partly derived from the first author's doctoral thesis submitted to Victoria University, Australia. An earlier version of the article was presented at The British Academy of Management Conference and was awarded Best Paper Award in leadership track. Only an abstract of the paper was published in the conference proceedings. 


\section{References}

Ahearne, M., Mathieu, J. \& Rapp, A. (2005), "To empower or not to empower your sales force? An empirical examination of the influence of leadership empowerment behavior on customer satisfaction and performance", Journal of Applied Psychology, Vol. 90, No. 5, pp. 945-955.

Amabile, T. M. (1983), "The social psychology of creativity: A componential conceptualization", Journal of Personality and Social Psychology, Vol. 45, No. 2, pp. 357-376.

Amabile, T. M. (1996). Creativity in context, CO: Westview Press., Boulder.

Arnold, J. A., Arad, S., Rhoades, J. A. \& Drasgow, F. (2000), "The empowering leadership questionnaire: The construction and validation of a new scale for measuring leader behaviors", Journal of Organizational Behavior, Vol. 21, No. 3, pp. 249-269.

Aryee, S., Kim, T.-Y., Zhou, Q. \& Ryu, S. (2019), "Customer service at altitude: effects of empowering leadership", International Journal of Contemporary Hospitality Management, Vol. 31, No. 9, pp. 3722-3741.

Babakus, E., Yavas, U., Karatepe, O. M. \& Avci, T. (2003), "The effect of management commitment to service quality on employees' affective and performance outcomes", Journal of the Academy of marketing Science, Vol. 31, No. 3, pp. 272-286.

Bandura, A. J. P. R. (1977), "Self-efficacy: toward a unifying theory of behavioral change", 84, No. 2, pp. 191.

Baum, T., Mooney, S. K., Robinson, R. N. \& Solnet, D. (2020), "COVID-19's impact on the hospitality workforce-new crisis or amplification of the norm?", International Journal of Contemporary Hospitality Management, Vol. 32, No. 9, pp. 2813-2829.

Bavik, A. (2020), "A systematic review of the servant leadership literature in management and hospitality", International Journal of Contemporary Hospitality Management, Vol. 32, No. 1, pp. 347-382.

Birkeland, M. S., Nielsen, M. B., Hansen, M. B., Knardahl, S. \& Heir, T. (2017), "The impact of a workplace terrorist attack on employees' perceptions of leadership: A longitudinal study from pre-to postdisaster", The Leadership Quarterly,Vol. 28, No. 5, pp. 659-671.

Blau, P. M. (1964). Exchange and power in social life. New Brunswick, Wiley, New York.

Botero, I. C. \& Van Dyne, L. (2009), "Employee voice behavior: Interactive effects of LMX and power distance in the United States and Colombia", Management Communication Quarterly, Vol. 23, No. 1, pp. 84-104.

Boukis, A., Koritos, C., Daunt, K. L. \& Papastathopoulos, A. J. (2020), "Effects of customer incivility on frontline employees and the moderating role of supervisor leadership style", Tourism Management, Vol. 77, No., pp. 103997.

Byun, G., Lee, S., Karau, S. J. \& Dai, Y. (2020), "The trickle-down effect of empowering leadership: a boundary condition of performance pressure", Leadership Organization Development Journal, Vol. 41, No. 3, pp. 399-414.

Carmeli, A., Schaubroeck, J. \& Tishler, A. (2011), "How CEO empowering leadership shapes top management team processes: Implications for firm performance", The Leadership Quarterly, Vol. 22, No. 2, pp. 399-411.

Cheong, M., Spain, S. M., Yammarino, F. J. \& Yun, S. (2016), "Two faces of empowering leadership: Enabling and burdening", The Leadership Quarterly,Vol. 27, No. 4, pp. 602616. 
Cheong, M., Yammarino, F. J., Dionne, S. D., Spain, S. M. \& Tsai, C.-Y. (2019), "A review of the effectiveness of empowering leadership", The Leadership Quarterly, Vol. 30, No. 1, pp. 3458.

Chiang, C.-F. \& Chen, J.-a. J. J. (2020), "How Empowering Leadership and a Cooperative Climate Influence Employees' Voice Behavior and Knowledge Sharing in the Hotel Industry", ournal of Quality Assurance in Hospitality Tourism Management, Vol., No., pp. 1-20.

Chon, K. K.-S. \& Zoltan, J. (2019), "Role of servant leadership in contemporary hospitality", International Journal of Contemporary Hospitality Management, Vol. 31, No. 8, pp. 33713394.

Clark, R. A., Hartline, M. D. \& Jones, K. C. (2009), "The effects of leadership style on hotel employees' commitment to service quality", Cornell Hospitality Quarterly, Vol. 50, No. 2, pp. 209-231.

Conger, J. A. \& Kanungo, R. N. (1988), "The empowerment process: Integrating theory and practice", Academy of Management Review, Vol. 13, No. 3, pp. 471-482.

Cook, D. J., Mulrow, C. D. \& Haynes, R. B. (1997), "Systematic reviews: Synthesis of best evidence for clinical decisions", Annals of Internal Medicine, Vol. 126, No. 5, pp. 376-380.

Cook, J. D. (1981). The experience of work: A compendium and review of 249 measures and their use, Academic Press, London; New York.

Costa Jr, P. T. \& Mccrae, R. R. (2008). The Revised NEO Personality Inventory (NEO-PI-R), Sage Publications, Inc, Thousand Oaks, CA.

Crossan, M. M. \& Apaydin, M. (2010), "A multi-dimensional framework of organizational innovation: A systematic review of the literature", Journal of management studies, Vol. 47, No. 6, pp. 1154-1191.

Cummings, G., Macgregor, T., Davey, M., Lee, H., Wongd, C., Lo, E., Muise, M. \& Stafford, E. (2010), "Leadership styles and outcome patterns for the nursing workforce and work environment: A systematic review", International Journal of Nursing Studies, Vol. 47, No., pp. 363-385.

Cunha, M. P. E., Fortes, A., Gomes, E., Rego, A. \& Rodrigues, F. (2019), "Ambidextrous leadership, paradox and contingency: evidence from Angola", The International Journal of Human Resource Management, Vol. 30, No. 4, pp. 702-727.

Do, H., Budhwar, P. S. \& Patel, C. (2018), "Relationship between innovation-led HR policy, strategy, and firm performance: A serial mediation investigation", Human Resource Management, Vol. 57, No. 5, pp. 1271-1284.

Elsetouhi, A. M., Hammad, A. A., Nagm, A.-E. A. \& Elbaz, A. M. (2018), "Perceived leader behavioral integrity and employee voice in SMEs travel agents: The mediating role of empowering leader behaviors", Tourism Management, Vol. 65, No., pp. 100-115.

Eva, N., Robin, M., Sendjaya, S., Van Dierendonck, D. \& Liden, R. C. (2019), "Servant leadership: A systematic review and call for future research", The Leadership Quarterly,Vol. 30, No. 1, pp. 111-132.

Festinger, L. (1954), "A theory of social comparison processes", Human relations, Vol. 7, No. 2, pp. 117-140.

Fong, K. H. \& Snape, E. (2015), "Empowering leadership, psychological empowerment and employee outcomes Testing a multi-level mediating model", British Journal of Management, Vol. 26, No. 1, pp. 126-138. 
Gill, C. \& Caza, A. (2018), "An investigation of authentic leadership's individual and group influences on follower responses", Journal of Management Studies, Vol. 44, No. 2, pp. 530554.

Gui, C., Luo, A., Zhang, P. \& Deng, A. (2020), "A meta-analysis of transformational leadership in hospitality research", International Journal of Contemporary Hospitality Management, Vol. 32, No. 5, pp. 2137-2154.

Hassi, A. (2019), "Empowering leadership and management innovation in the hospitality industry context", International Journal of Contemporary Hospitality Management, Vol. 31, No. 4, pp. 1785-1800.

Hill, N. S. \& Bartol, K. M. (2016), "Empowering leadership and effective collaboration in geographically dispersed teams", Personnel Psychology,Vol. 69, No. 1, pp. 159-198.

Hoang, G., Wilson-Evered, E. \& Lockstone-Binney, L. (2019), "Leading innovation among tourism small and medium enterprises: Examining the mediating role of climate for innovation", Leadership \& Organization Development Journal, Vol. 40, No. 5, pp. 647666.

Hoang, G., Wilson-Evered, E. \& Lockstone-Binney, L. (2020), "Leaders influencing innovation: a qualitative study exploring the role of leadership and organizational climate in Vietnamese tourism SMEs", Employee Relations: The International Journal, Vol. 43, No. 2, pp. 416-437.

Hobfoll, S. E. (1989), "Conservation of resources: a new attempt at conceptualizing stress", American psychologist, Vol. 44, No. 3, pp. 513-524.

Hon, A. (2011), "Enhancing employee creativity in the Chinese context: The mediating role of employee self-concordance", International Journal of Hospitality Management, Vol. 30, No. 2, pp. 375-384.

Hon, A. (2012), "Shaping environments conductive to creativity The role of intrinsic motivation", Cornell Hospitality Quarterly, Vol. 53, No. 1, pp. 53 -64.

Hon, A. \& Chan, W. (2012), "Team creative performance: The roles of empowering leadership, creative-rlated motivation, and task interdependence", Cornell Hospitality Quarterly, Vol. 54, No. 2, pp. 199-210.

Hong, Y., Liao, H., Raub, S. \& Han, J. H. (2016), "What it takes to get proactive: An integrative multilevel model of the antecedents of personal initiative", Journal of Applied Psychology, Vol. 101, No. 5, pp. 687.

House, R. J., Hanges, P. J., Javidan, M., Dorfman, P. W. \& Gupta, V. (2004). Culture, leadership, and organizations: The GLOBE study of 62 societies, Sage publications, Thousand Oaks, CA.

Huertas-Valdivia, I., Gallego-Burín, A. R. \& Lloréns-Montes, F. J. (2019), "Effects of different leadership styles on hospitality workers", Tourism management, Vol. 71, No., pp. 402-420.

Huertas-Valdivia, I., Llorens-Montes, F. J. \& Ruiz-Moreno, A. (2018), "Achieving engagement among hospitality employees: A serial mediation model", International Journal of Contemporary Hospitality Management, Vol. 30, No. 1, pp. 217-241.

Humphrey, S. E., Nahrgang, J. D. \& Morgeson, F. P. (2007), "Integrating motivational, social, and contextual work design features: A meta-analytic summary and theoretical extension of the work design literature", Journal of Applied Psychology, Vol. 92, No. 5, pp. 1332-1356.

Hunter, E. M., Neubert, M. J., Perry, S. J., Witt, L., Penney, L. M. \& Weinberger, E. (2013), "Servant leaders inspire servant followers: Antecedents and outcomes for employees and the organization", The Leadership Quarterly, Vol. 24, No. 2, pp. 316-331. 
Hunter, S., Bedell, K. \& Mumford, M. (2007), "Climate for creativity: A quantitative review", Creativity Research Journal,Vol. 19, No. 1, pp. 69-90.

Hunter, S. T., Cushenbery, L. D. \& Jayne, B. (2017), "Why dual leaders will drive innovation: Resolving the exploration and exploitation dilemma with a conservation of resources solution", Journal of Organizational Behavior, Vol. 38, No. 8, pp. 1183-1195.

Khan, K., Kunz, R., Kleijnen, J. \& Antes, G. (2003), "Five steps to conducting a systematic review", Journal of the Royal Society of Medicine, Vol. 96, No. 3, pp. 118-121.

Khosrowjerdi, M., Sundqvist, A. \& Byström, K. (2020), "Cultural patterns of information source use: A global study of 47 countries", Journal of the Association for Information Science Technology, Vol. 71, No. 6, pp. 711-724.

Kim, H. J. \& Agrusa, J. (2011), "Hospitality service employees' coping styles: The role of emotional intelligence, two basic personality traits, and socio-demographic factors", International Journal of Hospitality Management, Vol. 30, No. 3, pp. 588-598.

Kirkman, B. L., Chen, G., Farh, J.-L., Chen, Z. X. \& Lowe, K. B. (2009), "Individual power distance orientation and follower reactions to transformational leaders: A cross-level, cross-cultural examination", Academy of management journal,Vol. 52, No. 4, pp. 744-764.

Klassen, T. P., Jadad, A. R. \& Moher, D. (1998), "Guides for reading and interpreting systematic reviews", Archives of Pediatric \& Adolescent Medicine, Vol. 157, No. 7, pp. 700-704.

Konczak, L. J., Stelly, D. J. \& Trusty, M. L. (2000), "Defining and measuring empowering leader behaviors: Development of an upward feedback instrument", Educational Psychological measurement, Vol. 60, No. 2, pp. 301-313.

Lee, A., Willis, S. \& Tian, A. W. (2018), "Empowering leadership: A meta-analytic examination of incremental contribution, mediation, and moderation", Journal of Organizational Behavior, Vol. 39, No. 3, pp. 306-325.

Lim, S. \& Gon, E. (2021), "Fostering absorptive capacity and facilitating innovation in hospitality organizations through empowering leadership", International Journal of Hospitality Management, Vol. 94, No., pp. 102780.

Lim, W. M. \& To, W.-M. (2021), "The economic impact of a global pandemic on the tourism economy: the case of COVID-19 and Macao's destination-and gambling-dependent economy", Current Issues in Tourism, Vol. In printing, No., pp. 1-12.

Lin, M., Ling, Q., Luo, Z. \& Wu, X. (2019), "Why does empowering leadership occur and matter? A multilevel study of Chinese hotels", Tourism Management Perspectives, Vol. 32, No., pp. 100556.

Lin, M., Zhang, X., Ng, B. C. S. \& Zhong, L. (2020), "To Empower or Not to Empower? Multilevel Effects of Empowering Leadership on Knowledge Hiding", International Journal of Hospitality Management, Vol. 89, No., pp. 102540.

Ling, Y., Wei, L., Klimoski, R. J. \& Wu, L. (2015), "Benefiting from CEO's empowerment of TMTs: Does CEO-TMT dissimilarity matter?", The Leadership Quarterly, Vol. 26, No. 6, pp. 1066-1079.

Lorinkova, N., Pearsall, M. \& Sims, H. (2013), "Examining the differential longitudinal performance of directive versus empowering leadership in teams", Academy Of Management Journal, Vol. 56, No. 2, pp. 573-596.

Lorinkova, N. M. \& Perry, S. J. (2017), "When is empowerment effective? The role of leaderleader exchange in empowering leadership, cynicism, and time theft", Journal of Management, Vol. 43, No. 5, pp. 1631-1654. 
Luu, T. T. (2021), "Knowledge sharing in the hospitality context: The roles of leader humility, job crafting, and promotion focus", International Journal of Hospitality Management, Vol. 94, No., pp. 102848.

Manz, C. \& Sims Jr, H. (1987), "Leading workers to lead themselves: The external leadership of self-managing work teams", Administrative science quarterly, Vol. 32, No. 1, pp. 106-129.

Martin, S. L., Liao, H. \& Campbell, E. M. (2012), "Directive versus empowering leadership: A field rxperiment comparing impacts on task proficiency and proactivity", Academy of Management Journal, Vol. 56, No. 5, pp. 1372-1395.

Meyer, R. D., Dalal, R. S. \& Hermida, R. (2010), "A review and synthesis of situational strength in the organizational sciences", Journal of Management Studies, Vol. 36, No. 1, pp. 121140.

Namasivayam, K., Guchait, P. \& Lei, P. (2014), "The influence of leader empowering behaviors and employee psychological empowerment on customer satisfaction", International Journal of Contemporary Hospitality Management, Vol. 26, No. 1, pp. 69-84.

Paulhus, D. L. \& Williams, K. M. (2002), "The dark triad of personality: Narcissism, Machiavellianism, and psychopathy", Journal of research in personality, Vol. 36, No. 6, pp. 556-563.

Pearce, C., Sims, H., Cox, J., Ball, G., Smith, K. \& Trevino, L. (2003), "Transactors, transformers and beyond: A multi-method development of a theoretical typology of leadership", Journal of Management Development, Vol. 22, No. 4, pp. 273-307.

Pierce, J. \& Aguinis, H. (2013), "The too-much-of-a-good-thing effect in management", Journal of Management Studies, Vol. 39, No. 2, pp. 313-338.

Raub, S. \& Liao, H. (2012), "Doing the right thing without being told: Joint effects of initiative climate and general self-efficacy on employee proactive customer service performance", Journal of applied psychology, Vol. 97, No. 3, pp. 651.

Raub, S. \& Robert, C. (2010), "Differential effects of empowering leadership on in-role and extrarole employee behaviors: Exploring the role of psychological empowerment and power values", Human relations, Vol. 63, No. 11, pp. 1743-1770.

Ryan, R. M. \& Deci, E. L. (2000), "Self-determination theory and the facilitation of intrinsic motivation, social development, and well-being", American psychologist,Vol. 55, No. 1, pp. 68.

Schneider, B. 1982. Interactional psychology and organizational behavior. Michigan State Univ East Lansing Dept of Psychology.

Schneider, B., Ehrhart, M. \& Macey, W. (2013), "Organizational climate and culture", Annual Review of Psychology, Vol. 64, No. 3, pp. 61-88.

Sharma, P. \& Kirkman, B. (2015), "Leveraging leaders: A literature review and future lines of inquiry for empowering leadership research", Group \& Organization Management,Vol. 40, No. 2, pp. 193-237.

Spreitzer, G. (1995), "Psychological empowerment in the workplace: dimensions, measurement, and validation", Academy of Management Journal,Vol. 38, No., pp. 1442-1465.

Spreitzer, G., Sutcliffe, K., Dutton, J., Sonenshein, S. \& Grant, A. M. (2005), "A socially embedded model of thriving at work", Organization science, Vol. 16, No. 5, pp. 537-549.

Srivastava, A., Bartol, K. M. \& Locke, E. A. (2006), "Empowering leadership in management teams effects on knowledge sharing, efficacy, and performance", Academy of Management Journal,Vol. 49, No. 6, pp. 1239-1251. 
Stoker, J. I., Garretsen, H. \& Lammers, J. (2021), "Leading and Working From Home in Times of COVID-19: On the Perceived Changes in Leadership Behaviors", Journal of Leadership Organizational Studies, Vol. In printing, No., pp. 1-11.

Tuckey, M. R., Bakker, A. B. \& Dollard, M. F. (2012), "Empowering leaders optimize working conditions for engagement: a multilevel study", Journal of Occupational Health Psychology, Vol. 17, No. 1, pp. 15-27.

Tung, H. L. \& Chang, Y. H. (2011), "Effects of empowering leadership on performance in management team", Journal of Chinese Human Resources Management, Vol. 2, No. 1, pp. 43-60.

Vecchio, R. P., Justin, J. E. \& Pearce, C. L. (2010), "Empowering leadership: An examination of mediating mechanisms within a hierarchical structure", The Leadership Quarterly, Vol. 21, No. 3, pp. 530-542.

Wang, Z. \& Xie, Y. (2020), "Authentic leadership and employees' emotional labour in the hospitality industry", International Journal of Contemporary Hospitality Management, Vol. 32, No. 2, pp. 797-814.

West, M. A. (1990). The social psychology of innovation in groups. In: FARR, M. W. J. (ed.) Innovation and creativity at work: Psychological and organizational strategies. John Wiley \& Sons Chichester.

Wu, C.-M. \& Chen, T.-J. (2015), "Psychological contract fulfillment in the hotel workplace: Empowering leadership, knowledge exchange, and service performance", International Journal of Hospitality Management, Vol. 48, No., pp. 27-38.

Zhang, J., Xie, C., Wang, J., Morrison, A. M. \& Coca-Stefaniak, J. A. (2020), "Responding to a major global crisis: the effects of hotel safety leadership on employee safety behavior during COVID-19", International Journal of Contemporary Hospitality Management, Vol. 32, No. 11, pp. 3365-3389.

Zhang, X. \& Bartol, K. M. (2010), "Linking empowering leadership and employee creativity The influence of psychological empowerment, intrinsic motivation, and creative process engagement", Academy of Management Journal,Vol. 53, No. 1, pp. 107-128.

Zhang, X. \& Zhou, J. (2014), "Empowering leadership, uncertainty avoidance, trust, and employee creativity: Interaction effects and a mediating mechanism", Organizational Behavior and Human Decision Processes, Vol. 124, No. 2, pp. 150-164.

Zhou, X., Ma, J. \& Dong, X. (2018), "Empowering supervision and service sabotage: A moderated mediation model based on conservation of resources theory", Tourism Management, Vol. 64, No., pp. 170-187.

Zohar, D. \& Luria, G. (2005), "A multilevel model of safety climate: cross-level relationships between organization and group-level climates", Journal of applied psychology,Vol. 90, No. 4, pp. 616. 


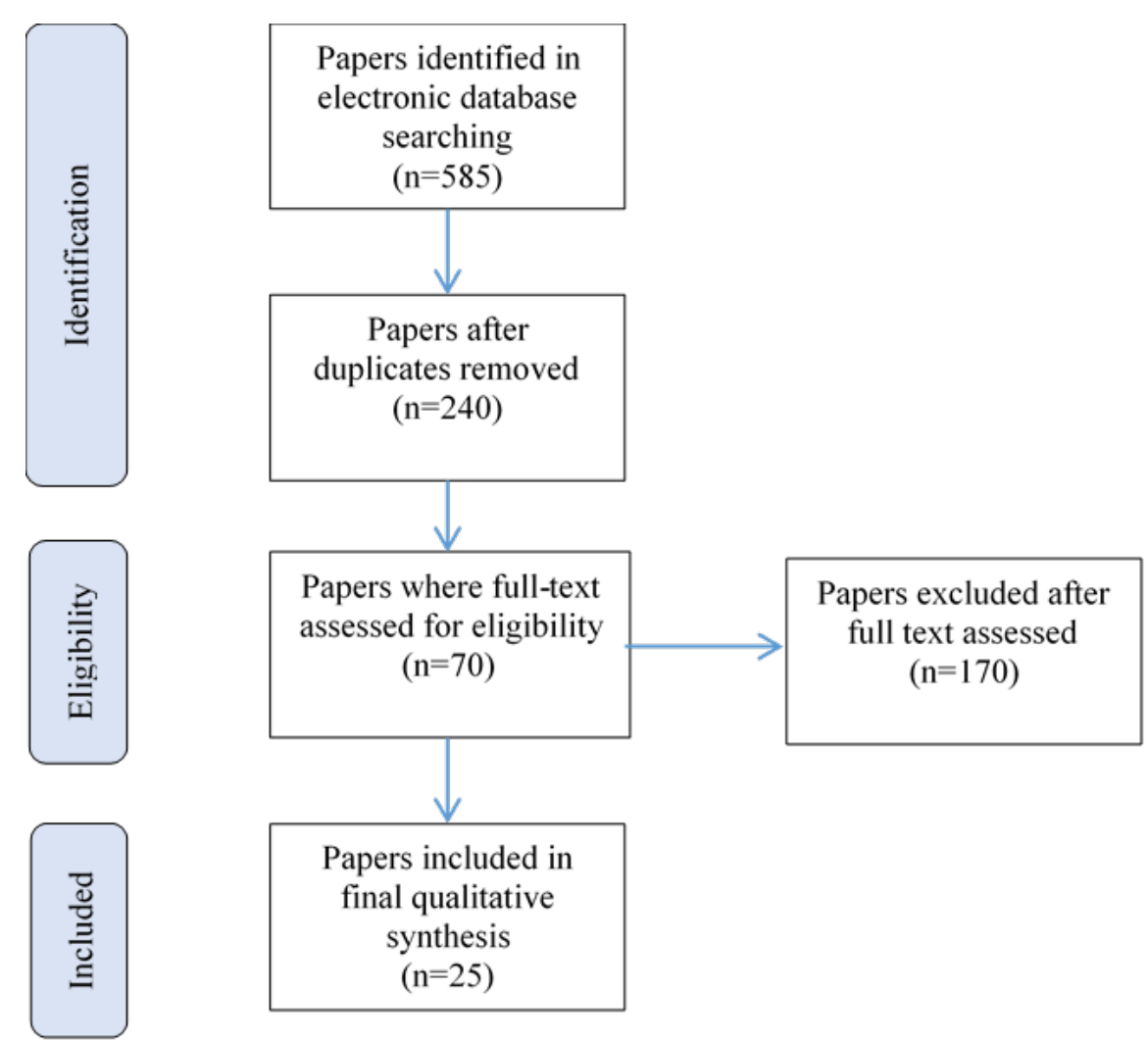

Figure 1. Flow chart of article search 


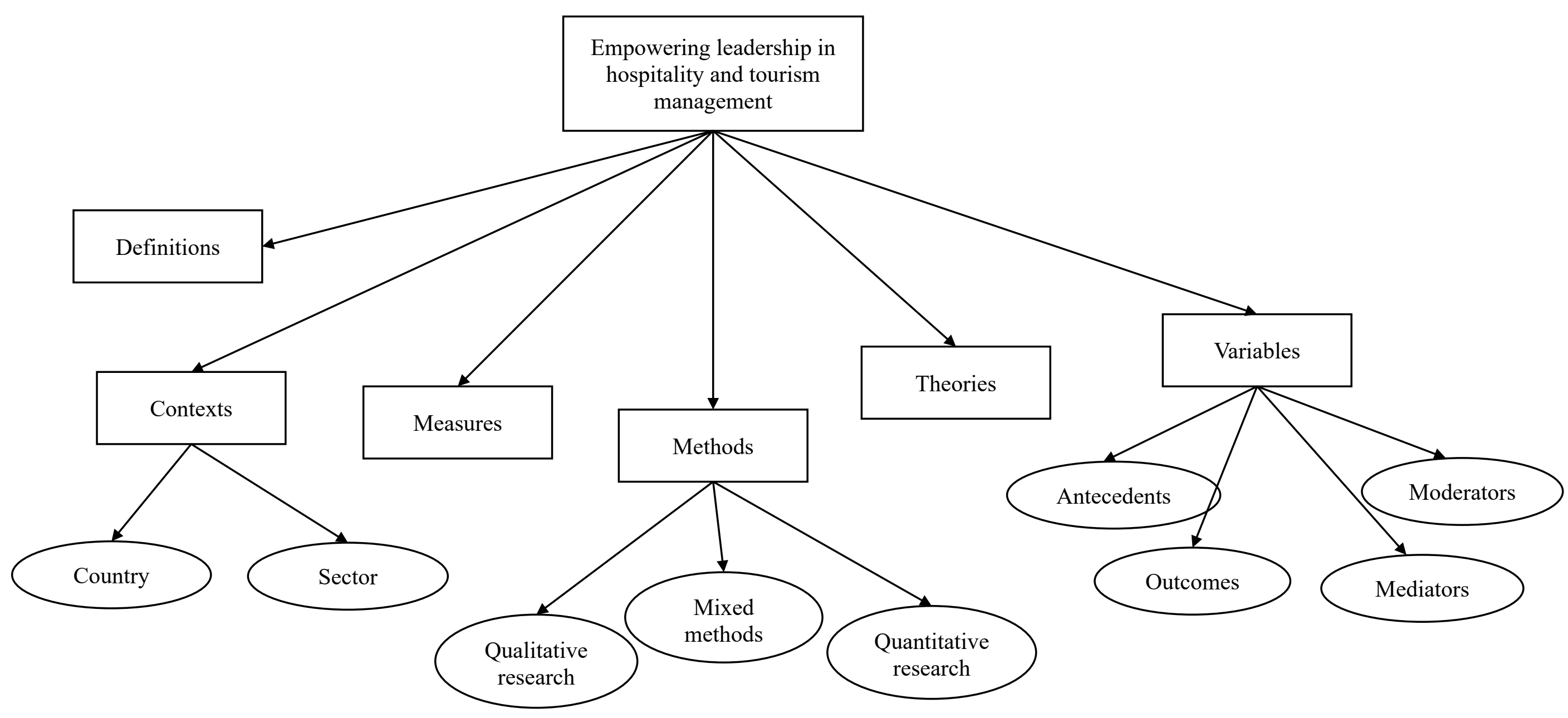

Figure 2. Data analysis procedure of the SLR 


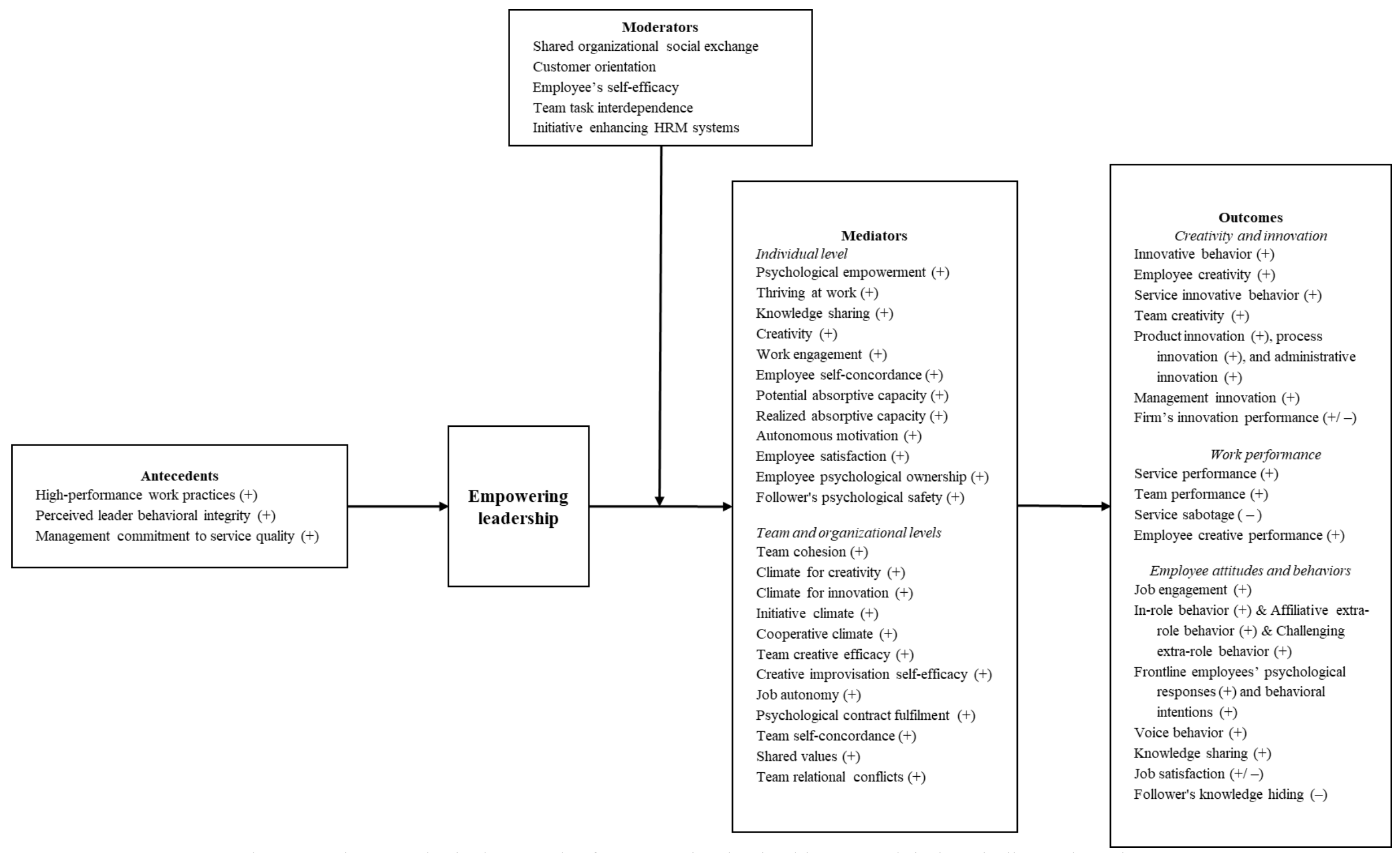

Figure 3. The nomological network of empowering leadership research in hospitality and tourism

Note: $+/$ - symbols refer to the positive/negative relationships between empowering leadership and the variables 
Table 1. Number of articles published in scholarly journals focusing on empowering leadership in hospitality and tourism

\begin{tabular}{|c|c|}
\hline Journal & Number of articles \\
\hline Cornell Hospitality Quarterly & 4 \\
\hline International Journal of Contemporary Hospitality Management & 4 \\
\hline International Journal of Hospitality Management & 4 \\
\hline Tourism Management & 4 \\
\hline Academy of Management Journal & 1 \\
\hline Human Relations & 1 \\
\hline International Journal of Quality and Service Sciences & 1 \\
\hline Journal of Applied Psychology & 1 \\
\hline Journal of Chinese Human Resource Management & 1 \\
\hline Journal of Quality Assurance in Hospitality \& Tourism & 1 \\
\hline Leadership \& Organization Development Journal & 1 \\
\hline Tourism Management Perspectives & 1 \\
\hline Tourism: An International Interdisciplinary Journal & 1 \\
\hline Total & 25 \\
\hline
\end{tabular}


Table 2. Summary of empowering leadership studies in tourism and hospitality management

\begin{tabular}{|c|c|c|c|c|c|c|c|c|c|c|c|c|}
\hline Authors & Measure & Methods & $\begin{array}{c}\text { Data } \\
\text { collection }\end{array}$ & $\begin{array}{l}\text { Context/ } \\
\text { Country }\end{array}$ & Sample & Antecedents & $\begin{array}{c}\text { Independent } \\
\text { variable }\end{array}$ & Mediators & Moderators & Outcomes & Theories & Main findings \\
\hline $\begin{array}{l}\text { Huertas- } \\
\text { Valdivia et } \\
\text { al. (2018) }\end{array}$ & $\begin{array}{l}\text { Ahearne et al. } \\
(2005) 12 \text {-item } \\
\text { scale }\end{array}$ & Quantitative & $\begin{array}{l}\text { Questionnaire } \\
\text { survey }\end{array}$ & $\begin{array}{l}329 \text { hotels } \\
\text { in Spain }\end{array}$ & $\begin{array}{l}340 \\
\text { employees }\end{array}$ & $\begin{array}{l}\text { High- } \\
\text { performance } \\
\text { work } \\
\text { practices } \\
(\mathrm{b}=0.714, \\
\mathrm{p}<0.001)\end{array}$ & NA & $\begin{array}{l}\text { Empowering leadership } \\
(\beta=0.283, \mathrm{p}<0.001) \\
\text { and Psychological } \\
\text { empowerment }(\beta= \\
0.535, \mathrm{p}<0.001)\end{array}$ & NA & $\begin{array}{l}\text { Job engagement }(\beta= \\
0.159, \mathrm{p}<0.01)\end{array}$ & NA & $\begin{array}{l}\text { Psychological empowerment and } \\
\text { empowering leadership intervene the high- } \\
\text { performance work practices-engagement } \\
\text { relationship. }\end{array}$ \\
\hline $\begin{array}{l}\text { Aryee et } \\
\text { al. (2019) }\end{array}$ & $\begin{array}{l}\text { Ahearne et al. } \\
(2005) 12 \text {-item } \\
\text { scale }\end{array}$ & Quantitative & $\begin{array}{l}\text { Questionnaire } \\
\text { survey }\end{array}$ & $\begin{array}{l}\text { A South } \\
\text { Korean } \\
\text { airline }\end{array}$ & $\begin{array}{l}283 \\
\text { matched } \\
\text { employee- } \\
\text { supervisor } \\
\text { dyads }\end{array}$ & NA & $\begin{array}{l}\text { Empowering } \\
\text { Leadership }\end{array}$ & $\begin{array}{l}\text { Thriving at work ( } \beta= \\
0.38, \mathrm{p}<0.001 \text { ) }\end{array}$ & $\begin{array}{l}\text { Shared } \\
\text { organizationa } \\
1 \\
\text { social } \\
\text { exchange \& } \\
\text { Customer } \\
\text { orientation } \\
\end{array}$ & $\begin{array}{l}\text { Service performance } \\
(\beta=0.19, p<0.05)\end{array}$ & $\begin{array}{l}\text { Socially embedded } \\
\text { model and Self- } \\
\text { determination theory }\end{array}$ & $\begin{array}{l}\text { Customer orientation and empowering } \\
\text { leadership promote service performance. } \\
\text { Thriving at work mediates these } \\
\text { associations. } \\
\text { Customer orientation moderates the } \\
\text { empowering leadership and thriving at } \\
\text { work association. } \\
\text { Shared organizational social exchange } \\
\text { strengthens the empowering leadership - } \\
\text { service performance association. }\end{array}$ \\
\hline $\begin{array}{l}\text { Raub and } \\
\text { Robert } \\
(2010)\end{array}$ & $\begin{array}{l}\text { Arnold et al. } \\
(2000) 15 \text {-item } \\
\text { scale }\end{array}$ & Quantitative & $\begin{array}{l}\text { Questionnaire } \\
\text { survey }\end{array}$ & $\begin{array}{l}\text { A division } \\
\text { of a hotel } \\
\text { chain in the } \\
\text { Middle East } \\
\text { and Asia- } \\
\text { Pacific }\end{array}$ & $\begin{array}{l}541 \text { front- } \\
\text { line service } \\
\text { employees } \\
\text { and } 541 \\
\text { supervisors }\end{array}$ & NA & $\begin{array}{l}\text { Empowering } \\
\text { Leadership }\end{array}$ & $\begin{array}{l}\text { Psychological } \\
\text { empowerment }(\beta= \\
0.31, \mathrm{p}<0.001)\end{array}$ & $\begin{array}{l}\text { Low versus } \\
\text { high power } \\
\text { values }\end{array}$ & $\begin{array}{l}\text { In-role behavior }(\beta= \\
0.10, \mathrm{p}<0.01) \& \\
\text { Affiliative extra-role } \\
\text { behavior }(\beta=0.15, \mathrm{p} \\
<0.01) \& \\
\text { Challenging extra- } \\
\text { role behavior }(\beta= \\
0.31, \mathrm{p}<0.001)\end{array}$ & $\begin{array}{l}\text { Self-determination } \\
\text { theory }\end{array}$ & $\begin{array}{l}\text { Empowering leadership affects employee } \\
\text { behaviors directly and via psychological } \\
\text { empowerment. Power values moderate this } \\
\text { relationship. }\end{array}$ \\
\hline $\begin{array}{l}\text { Boukis et } \\
\text { al. }(2020)\end{array}$ & & Quantitative & $\begin{array}{l}\text { Scenario- } \\
\text { based } \\
\text { experimental } \\
\text { and } \\
\text { questionnaire } \\
\text { survey }\end{array}$ & $\begin{array}{l}38 \text { five-star } \\
\text { hotels in the } \\
\text { UAE }\end{array}$ & $\begin{array}{l}122 \text { front- } \\
\text { line service } \\
\text { employees }\end{array}$ & $\mathrm{NA}$ & $\begin{array}{l}\text { Customer } \\
\text { incivility }\end{array}$ & NA & $\begin{array}{l}\text { Empowering } \\
\text { vs. laissez- } \\
\text { faire } \\
\text { leadership } \\
\text { styles }\end{array}$ & $\begin{array}{l}\text { Frontline employees' } \\
\text { psychological } \\
\text { responses and } \\
\text { behavioral intentions } \\
\text { (Role stress, } \\
\text { Rumination, } \\
\text { Retaliation, and } \\
\text { Withdrawal) } \\
\end{array}$ & $\begin{array}{l}\text { The job demands- } \\
\text { resources and } \\
\text { Conservation of } \\
\text { resources } \\
\text { frameworks }\end{array}$ & $\begin{array}{l}\text { Empowering leadership mitigates the } \\
\text { reducing effects of customer incivility } \\
\text { forms on role stress, rumination, retaliation, } \\
\text { and withdrawal intentions better than } \\
\text { laissez-faire leadership. }\end{array}$ \\
\hline $\begin{array}{l}\text { Huertas- } \\
\text { Valdivia et } \\
\text { al. (2019) }\end{array}$ & $\begin{array}{l}\text { Ahearne et al. } \\
(2005) 12 \text {-item } \\
\text { scale }\end{array}$ & Quantitative & $\begin{array}{l}\text { Questionnaire } \\
\text { survey }\end{array}$ & $\begin{array}{l}\text { Spanish } \\
\text { hotels }\end{array}$ & $\begin{array}{l}340 \\
\text { employees }\end{array}$ & $\mathrm{NA}$ & $\begin{array}{l}\text { Empowering, } \\
\text { paradoxical and } \\
\text { servant } \\
\text { leadership }\end{array}$ & $\begin{array}{l}\text { Psychological } \\
\text { empowerment }(\beta= \\
0.389, \mathrm{p}<0.01)\end{array}$ & NA & $\begin{array}{l}\text { Job engagement }(\beta= \\
0.270, p<0.01)\end{array}$ & $\begin{array}{l}\text { Self-determination } \\
\text { theory }\end{array}$ & $\begin{array}{l}\text { Empowering and paradoxical leadership } \\
\text { positively relate to psychological } \\
\text { empowerment, while empowering and } \\
\text { servant leadership are related to } \\
\text { engagement. Psychological empowerment } \\
\text { enhances job engagement. }\end{array}$ \\
\hline $\begin{array}{l}\text { Tung and } \\
\text { Chang } \\
(2011)\end{array}$ & $\begin{array}{l}\text { Ahearne et al. } \\
(2005) 12 \text {-item } \\
\text { scale }\end{array}$ & Quantitative & $\begin{array}{l}\text { Questionnaire } \\
\text { survey }\end{array}$ & $\begin{array}{l}\text { An } \\
\text { internationa } \\
1 \text { fast-food } \\
\text { chain in } \\
\text { Taiwan }\end{array}$ & $\begin{array}{l}261 \text { team } \\
\text { members } \\
\text { from } \\
79 \\
\text { managemen } \\
\mathrm{t} \text { teams }\end{array}$ & NA & $\begin{array}{l}\text { Empowering } \\
\text { Leadership }\end{array}$ & $\begin{array}{l}\text { Knowledge sharing }(\beta \\
=0.42, \mathrm{p}<0.001) \text { and } \\
\text { team cohesion }(\beta= \\
0.38, \mathrm{p}<0.001)\end{array}$ & NA & $\begin{array}{l}\text { Team performance } \\
(\beta=0.39, p<0.001)\end{array}$ & $\begin{array}{l}\text { Empowerment } \\
\text { theory }\end{array}$ & $\begin{array}{l}\text { Empowering leadership enhances team } \\
\text { performance. Knowledge sharing and team } \\
\text { cohesion were found to mediate this } \\
\text { relationship. }\end{array}$ \\
\hline $\begin{array}{l}\text { Hassi } \\
(2019)\end{array}$ & $\begin{array}{l}\text { Ahearne et al. } \\
(2005) 12 \text {-item } \\
\text { scale }\end{array}$ & Quantitative & $\begin{array}{l}\text { Questionnaire } \\
\text { survey }\end{array}$ & $\begin{array}{l}127 \text { hotels } \\
\text { in Morocco }\end{array}$ & $\begin{array}{l}127 \\
\text { administrati } \\
\text { ve } \\
\text { department } \\
\text { managers } \\
\end{array}$ & $\mathrm{NA}$ & $\begin{array}{l}\text { Empowering } \\
\text { Leadership }\end{array}$ & $\begin{array}{l}\text { Climate for Creativity } \\
(\beta=0.542, p<0.01)\end{array}$ & $\mathrm{NA}$ & $\begin{array}{l}\text { Management } \\
\text { innovation }(\beta= \\
0.517, \mathrm{p}<0.01)\end{array}$ & NA & $\begin{array}{l}\text { Empowering leadership promotes } \\
\text { management innovation through climate for } \\
\text { creativity. }\end{array}$ \\
\hline
\end{tabular}




\begin{tabular}{|c|c|c|c|c|c|c|c|c|c|c|c|c|}
\hline & & & & & $\begin{array}{l}\text { and front } \\
\text { desk } \\
\text { managers }\end{array}$ & & & & & & & \\
\hline $\begin{array}{l}\text { Slåsten et } \\
\text { al. (2011) }\end{array}$ & $\begin{array}{l}\text { Babakus et al. } \\
(2003)\end{array}$ & Quantitative & $\begin{array}{l}\text { Questionnaire } \\
\text { survey }\end{array}$ & $\begin{array}{l}\text { Norwegian } \\
\text { hotels }\end{array}$ & $\begin{array}{l}72 \text { hotel } \\
\text { frontline } \\
\text { service } \\
\text { employees }\end{array}$ & $\mathrm{NA}$ & $\begin{array}{l}\text { Empowering } \\
\text { leadership \& } \\
\text { Humorous work } \\
\text { climate }\end{array}$ & $\begin{array}{l}\text { Creativity }(\beta=0.470, \\
p<0.001)\end{array}$ & NA & $\begin{array}{l}\text { Innovative behavior } \\
(\beta=0.634, \mathrm{p}<0.001)\end{array}$ & $\mathrm{NA}$ & $\begin{array}{l}\text { Empowering leadership and a humorous } \\
\text { work climate promote creativity of service } \\
\text { staff. } \\
\text { Creativity of service staff mediates the } \\
\text { associations between empowering } \\
\text { leadership, humorous work climate, and the } \\
\text { innovative behavior. }\end{array}$ \\
\hline $\begin{array}{l}\text { Srivastava } \\
\text { et al. } \\
(2006) \\
\end{array}$ & $\begin{array}{l}\text { Arnold et al. } \\
(2000) 15 \text {-item } \\
\text { scale }\end{array}$ & Quantitative & $\begin{array}{l}\text { Questionnaire } \\
\text { survey }\end{array}$ & $\begin{array}{l}102 \\
\text { medium- } \\
\text { sized US } \\
\text { hotels } \\
\end{array}$ & $\begin{array}{l}102 \text { teams } \\
\text { and } 389 \\
\text { managers }\end{array}$ & $\mathrm{NA}$ & $\begin{array}{l}\text { Empowering } \\
\text { leadership }\end{array}$ & $\begin{array}{l}\text { Knowledge sharing ( } \beta \\
=0.41, \mathrm{p}<0.01) \text { and } \\
\text { team efficacy }(\beta=0.51 \text {, } \\
\mathrm{p}<0.01)\end{array}$ & $\mathrm{NA}$ & $\begin{array}{l}\text { Team performance } \\
\text { (positive indirect } \\
\text { effect, } \beta \text { not } \\
\text { reported) }\end{array}$ & $\begin{array}{l}\text { Empowerment } \\
\text { theory }\end{array}$ & $\begin{array}{l}\text { Empowering leadership promotes } \\
\text { knowledge sharing and team efficacy, } \\
\text { which, in turn, enhance performance. }\end{array}$ \\
\hline $\begin{array}{l}\text { Zhou et al. } \\
(2018)\end{array}$ & $\begin{array}{l}\text { Manz and Sims } \\
(1987) 10 \text {-item } \\
\text { scale, revised } \\
\text { by Pearce and } \\
\text { Sims (2002) } \\
\end{array}$ & Quantitative & $\begin{array}{l}\text { Questionnaire } \\
\text { survey }\end{array}$ & $\begin{array}{l}11 \text { hotels in } \\
\text { China }\end{array}$ & $\begin{array}{l}220 \\
\text { available } \\
\text { employee- } \\
\text { supervisor } \\
\text { dyads } \\
\end{array}$ & $\mathrm{NA}$ & $\begin{array}{l}\text { Empowering } \\
\text { supervision }\end{array}$ & $\begin{array}{l}\text { Work engagement }(\beta= \\
0.26, p<0.01)\end{array}$ & $\begin{array}{l}\text { General self- } \\
\text { efficacy }\end{array}$ & $\begin{array}{l}\text { Service sabotage ( } \beta \\
=-0.22, \mathrm{p}<0.01)\end{array}$ & $\begin{array}{l}\text { Conservation of } \\
\text { resources theory }\end{array}$ & $\begin{array}{l}\text { Empowering leadership negatively affects } \\
\text { employees' service sabotage via work } \\
\text { engagement. Both indirect and direct } \\
\text { associations are moderated by self-efficacy. }\end{array}$ \\
\hline $\begin{array}{l}\text { Raub and } \\
\text { Robert } \\
\text { (2013) }\end{array}$ & $\begin{array}{l}\text { Arnold et al. } \\
(2000) 15 \text {-item } \\
\text { scale }\end{array}$ & Quantitative & $\begin{array}{l}\text { Questionnaire } \\
\text { survey }\end{array}$ & $\begin{array}{l}\text { A hotel } \\
\text { chain in } \\
\text { Asia-Pacific } \\
\text { and the } \\
\text { Middle East }\end{array}$ & $\begin{array}{l}640 \\
\text { frontline } \\
\text { service } \\
\text { staff and } \\
\text { their } \\
\text { managers } \\
\end{array}$ & $\mathrm{NA}$ & $\begin{array}{l}\text { Empowering } \\
\text { Leadership }\end{array}$ & $\begin{array}{l}\text { Psychological } \\
\text { empowerment }(\beta= \\
0.55, \mathrm{p}<0.001)\end{array}$ & $\mathrm{NA}$ & $\begin{array}{l}\text { Organizational } \\
\text { commitment }(\beta= \\
0.10, \mathrm{p}<0.01) \& \\
\text { Voice behavior }(\beta= \\
0.13, \mathrm{p}<0.01)\end{array}$ & & $\begin{array}{l}\text { Psychological empowerment mediates the } \\
\text { empowering leadership-organizational } \\
\text { commitment and empowering leadership- } \\
\text { voice behavior relationships. These effects } \\
\text { are reduced for high power distance } \\
\text { cultures. }\end{array}$ \\
\hline $\begin{array}{l}\text { Hon } \\
(2011)\end{array}$ & $\begin{array}{l}\text { Arnold et al. } \\
(2000) 15 \text {-item } \\
\text { scale }\end{array}$ & Quantitative & $\begin{array}{l}\text { Questionnaire } \\
\text { survey }\end{array}$ & $\begin{array}{l}20 \text { hotel } \\
\text { companies } \\
\text { in China }\end{array}$ & $\begin{array}{l}286 \\
\text { employees }\end{array}$ & NA & $\begin{array}{l}\text { Organizational } \\
\text { modernity, } \\
\text { Empowering } \\
\text { leadership, and } \\
\text { Co-workers } \\
\text { support and } \\
\text { helping } \\
\end{array}$ & $\begin{array}{l}\text { Employee self- } \\
\text { concordance }(\beta=0.24, \\
p<0.01)\end{array}$ & NA & $\begin{array}{l}\text { Employee creativity } \\
(\beta=0.33, p<0.01)\end{array}$ & $\begin{array}{l}\text { Theory of self- } \\
\text { concordance }\end{array}$ & $\begin{array}{l}\text { Organizational modernity, empowering } \\
\text { leadership, and colleague support and } \\
\text { helping are related to employee self- } \\
\text { concordance, which in turn is related to } \\
\text { employee creativity. }\end{array}$ \\
\hline $\begin{array}{l}\text { Lim and } \\
\text { Gon } \\
(2021)\end{array}$ & $\begin{array}{l}\text { Ahearne et al. } \\
(2005) 12 \text {-item } \\
\text { scale }\end{array}$ & Quantitative & $\begin{array}{l}\text { Questionnaire } \\
\text { survey }\end{array}$ & $\begin{array}{l}\text { European } \\
\text { and US } \\
\text { hospitality } \\
\text { firms }\end{array}$ & $\begin{array}{l}287 \\
\text { employees }\end{array}$ & $\mathrm{NA}$ & $\begin{array}{l}\text { Empowering } \\
\text { Leadership }\end{array}$ & $\begin{array}{l}\text { Potential absorptive } \\
\text { capacity }(\beta=0.67, \\
\mathrm{p}<0.001) \text { and realized } \\
\text { absorptive capacity }(\beta \\
=0.73, \mathrm{p}<0.001)\end{array}$ & NA & $\begin{array}{l}\text { Product innovation } \\
(\beta=.37,95 \% \text { CI } \\
[.20,1.10]), \text { process } \\
\text { innovation }(\beta=.39, \\
95 \% \text { CI }[.21,1.05]), \\
\text { and administrative } \\
\text { innovation }(\beta=.47, \\
95 \% \text { CI }[.34,1.18]) \\
\end{array}$ & $\begin{array}{l}\text { The integration of } \\
\text { motivation, } \\
\text { opportunity, and } \\
\text { ability (MOA) } \\
\text { framework and Self- } \\
\text { efficacy } \\
\text { perspective }\end{array}$ & $\begin{array}{l}\text { Empowering leadership positively } \\
\text { influences potential and realized absorptive } \\
\text { capacity. Absorptive capacity positively } \\
\text { influences innovation (i.e. product, process, } \\
\text { and administrative). Potential and realized } \\
\text { absorptive capacity mediates these } \\
\text { associations. }\end{array}$ \\
\hline $\begin{array}{l}\text { Chiang } \\
\text { and Chen } \\
(2020)\end{array}$ & $\begin{array}{l}15 \text { questions } \\
\text { obtained from } \\
\text { Srivastava } \\
\text { (2001) }\end{array}$ & Quantitative & $\begin{array}{l}\text { Questionnaire } \\
\text { survey }\end{array}$ & $\begin{array}{l}12 \text { five-star } \\
\text { hotels in } \\
\text { Taiwan }\end{array}$ & $\begin{array}{l}327 \\
\text { employees }\end{array}$ & NA & $\begin{array}{l}\text { Empowering } \\
\text { Leadership }\end{array}$ & $\begin{array}{l}\text { Cooperative climate }(\beta \\
=0.393, p<0.001) \\
\text { Job Autonomy }(\beta= \\
0.52, \mathrm{p}<0.001)\end{array}$ & NA & $\begin{array}{l}\text { Voice behavior }(\beta= \\
0.46, p<0.001) \& \\
\text { Knowledge sharing } \\
(\beta=0.20, p<0.001)\end{array}$ & $\begin{array}{l}\text { Self-determination } \\
\text { theory }\end{array}$ & $\begin{array}{l}\text { Empowering leadership and a cooperative } \\
\text { climate promote job autonomy, } \\
\text { encouraging employees' voice opinions and } \\
\text { knowledge sharing. }\end{array}$ \\
\hline $\begin{array}{l}\text { Hoang et } \\
\text { al. }(2019)\end{array}$ & $\begin{array}{l}5 \text {-item scale } \\
\text { developed by } \\
\text { Martin et al. } \\
\text { (2012), which } \\
\text { was adapted } \\
\text { from Ahearne } \\
\text { et al. (2005) } \\
\text { and Arnold et } \\
\text { al. (2000) }\end{array}$ & Quantitative & $\begin{array}{l}\text { Questionnaire } \\
\text { survey }\end{array}$ & $\begin{array}{l}37 \text { tourism } \\
\text { SMEs in } \\
\text { Vietnam }\end{array}$ & $\begin{array}{l}330 \\
\text { employees }\end{array}$ & $\mathrm{NA}$ & $\begin{array}{l}\text { Empowering } \\
\text { Leadership, } \\
\text { directive } \\
\text { leadership, } \\
\text { Initiating } \\
\text { structure } \\
\end{array}$ & $\begin{array}{l}\text { Climate for innovation } \\
(\beta=0.312, p<0.05)\end{array}$ & NA & $\begin{array}{l}\text { Innovation } \\
\text { performance }(\beta=- \\
0.314, \mathrm{p}<0.05)\end{array}$ & $\begin{array}{l}\text { Too-much-of-a- } \\
\text { good-thing theory, } \\
\text { Dual tuning theory, } \\
\text { and Regulatory } \\
\text { focus theory }\end{array}$ & $\begin{array}{l}\text { Climate for innovation mediated the } \\
\text { relationships between empowering } \\
\text { leadership and initiating structure and } \\
\text { innovation performance. } \\
\text { Initiating structure has a positive direct } \\
\text { association with innovation, empowering } \\
\text { leadership has a negative direct association } \\
\text { with innovation. }\end{array}$ \\
\hline
\end{tabular}




\begin{tabular}{|c|c|c|c|c|c|c|c|c|c|c|c|c|}
\hline $\begin{array}{l}\text { Wihuda et } \\
\text { al. (2017) }\end{array}$ & $\begin{array}{l}\text { Ahearne et al. } \\
(2005) 12 \text {-item } \\
\text { scale }\end{array}$ & Quantitative & $\begin{array}{l}\text { Questionnaire } \\
\text { survey }\end{array}$ & $\begin{array}{l}\text { Indonesian } \\
\text { hotels }\end{array}$ & $\begin{array}{l}121 \\
\text { frontline } \\
\text { employees }\end{array}$ & NA & $\begin{array}{l}\text { Empowering } \\
\text { Leadership }\end{array}$ & $\begin{array}{l}\text { Creative improvisation } \\
\text { self-efficacy }(\beta= \\
0.406, \mathrm{p}<0.01) \text { \& } \\
\text { Employee engagement } \\
(\beta=0.290, \mathrm{p}<0.01) \\
\end{array}$ & NA & $\begin{array}{l}\text { Employee service } \\
\text { innovative behavior } \\
(\beta=0.383, p<0.01)\end{array}$ & & $\begin{array}{l}\text { Empowering leadership positively affects } \\
\text { employee service innovative behavior. } \\
\text { Creative improvisation self-efficacy and } \\
\text { employee engagement partially mediated } \\
\text { this relationship. }\end{array}$ \\
\hline $\begin{array}{l}\text { Elsetouhi } \\
\text { et al. } \\
\text { (2018) }\end{array}$ & $\begin{array}{l}\text { Arnold et al. } \\
(2000) 15 \text {-item } \\
\text { scale }\end{array}$ & Quantitative & $\begin{array}{l}\text { Questionnaire } \\
\text { survey }\end{array}$ & $\begin{array}{l}\text { Egyptian } \\
\text { SME travel } \\
\text { agents }\end{array}$ & $\begin{array}{l}500 \\
\text { frontline } \\
\text { employees }\end{array}$ & $\begin{array}{l}\text { Perceived } \\
\text { leader } \\
\text { behavioral } \\
\text { integrity } \\
\end{array}$ & NA & $\begin{array}{l}\text { Empowering } \\
\text { Leadership }\end{array}$ & NA & $\begin{array}{l}\text { Employee voice } \\
(\beta=0.122, \mathrm{p}<0.05 ; \beta \\
=0.695, \mathrm{p}<0.001)\end{array}$ & $\begin{array}{l}\text { Social exchange } \\
\text { theory }\end{array}$ & $\begin{array}{l}\text { Perceived leader behavioral integrity } \\
\text { positively influences employee voice. } \\
\text { Empowering leadership mediates this } \\
\text { relationship. }\end{array}$ \\
\hline $\begin{array}{l}\text { Wu and } \\
\text { Chen } \\
(2015)\end{array}$ & $\begin{array}{l}\text { Arnold et al. } \\
(2000) 15 \text {-item } \\
\text { scale }\end{array}$ & Quantitative & $\begin{array}{l}\text { Questionnaire } \\
\text { survey }\end{array}$ & $\begin{array}{l}28 \\
\text { Taiwanese } \\
\text { tourism } \\
\text { hotels }\end{array}$ & $\begin{array}{l}258 \\
\text { employees }\end{array}$ & NA & $\begin{array}{l}\text { Empowering } \\
\text { Leadership }\end{array}$ & $\begin{array}{l}\text { Psychological } \\
\text { contract fulfilment }(\beta= \\
0.45, \mathrm{p}<0.01) \& \\
\text { Knowledge exchange } \\
(\beta=0.54, \mathrm{p}<0.01) \\
\end{array}$ & NA & $\begin{array}{l}\text { Service performance } \\
(\beta=0.62, p<0.05)\end{array}$ & $\begin{array}{l}\text { Social exchange } \\
\text { theory and } \\
\text { Psychological } \\
\text { contract theory }\end{array}$ & $\begin{array}{l}\text { Empowering leadership positively affects } \\
\text { service performance. } \\
\text { Psychological contract fulfillment mediates } \\
\text { the empowering leadership-knowledge } \\
\text { exchange relationship. } \\
\text { Knowledge exchange mediates the } \\
\text { psychological contract fulfillment-service } \\
\text { performance relationship. }\end{array}$ \\
\hline $\begin{array}{l}\text { Hon } \\
(2012)\end{array}$ & $\begin{array}{l}\text { Arnold et al. } \\
(2000) 15 \text {-item } \\
\text { scale }\end{array}$ & Quantitative & $\begin{array}{l}\text { Questionnaire } \\
\text { survey }\end{array}$ & $\begin{array}{l}31 \text { joint } \\
\text { ventures } \\
\text { and } \\
\text { multination } \\
\text { al } \\
\text { corporations } \\
\text { in the } \\
\text { hospitality } \\
\text { industry in } \\
\text { Shanghai } \\
\text { China } \\
\end{array}$ & $\begin{array}{l}250 \\
\text { employees } \\
\text { and } 31 \\
\text { team } \\
\text { managers }\end{array}$ & NA & $\begin{array}{l}\text { Empowering } \\
\text { leadership, } \\
\text { Climate for } \\
\text { creativity, Co- } \\
\text { worker support, } \\
\text { Task } \\
\text { conflict, } \\
\text { Personal conflict }\end{array}$ & $\begin{array}{l}\text { Autonomous } \\
\text { motivation }(\beta=0.36 \text {, } \\
p<0.01)\end{array}$ & NA & $\begin{array}{l}\text { Employee creative } \\
\text { performance } \\
\text { (positive indirect } \\
\text { effect, } \beta \text { not } \\
\text { reported) }\end{array}$ & $\begin{array}{l}\text { Self-determination } \\
\text { theory }\end{array}$ & $\begin{array}{l}\text { Climate for creativity, empowering } \\
\text { leadership, and coworker support enhance } \\
\text { creativity via autonomous motivation while } \\
\text { task and personal conflict negatively affect } \\
\text { autonomous motivation. }\end{array}$ \\
\hline $\begin{array}{l}\text { Hon and } \\
\text { Chan } \\
(2012)\end{array}$ & $\begin{array}{l}\text { Arnold et al. } \\
(2000) 15 \text {-item } \\
\text { scale }\end{array}$ & Quantitative & $\begin{array}{l}\text { Questionnaire } \\
\text { survey }\end{array}$ & $\begin{array}{l}52 \text { hotel } \\
\text { companies } \\
\text { in } \\
\text { Guangzhou, } \\
\text { China }\end{array}$ & $\begin{array}{l}286 \text { team } \\
\text { members } \\
\text { and } \\
52 \text { team } \\
\text { leaders }\end{array}$ & NA & $\begin{array}{l}\text { Empowering } \\
\text { Leadership }\end{array}$ & $\begin{array}{l}\text { Team self-concordance } \\
(\beta=0.34, \mathrm{p}<0.01) \\
\& \text { Team creative } \\
\text { efficacy }(\beta=0.31 \\
\mathrm{p}<0.01)\end{array}$ & $\begin{array}{l}\text { Team task } \\
\text { interdepende } \\
\text { nce }\end{array}$ & $\begin{array}{l}\text { Team creativity }(\beta= \\
0.26, p<0.01)\end{array}$ & $\begin{array}{l}\text { Self-determination } \\
\text { theory }\end{array}$ & $\begin{array}{l}\text { Team self-concordance and team creative } \\
\text { efficacy mediate the empowering } \\
\text { leadership-team creativity relationship. } \\
\text { Team task interdependence moderates the } \\
\text { direct associations of empowering } \\
\text { leadership and team self-concordance and } \\
\text { team creative efficacy and also moderates } \\
\text { the indirect association of empowering } \\
\text { leadership and team creativity. }\end{array}$ \\
\hline $\begin{array}{l}\text { Clark et al. } \\
(2009)\end{array}$ & $\begin{array}{l}\text { 8-item scale by } \\
\text { Cook et al. } \\
\text { (1981) }\end{array}$ & Quantitative & $\begin{array}{l}\text { Questionnaire } \\
\text { survey }\end{array}$ & $\begin{array}{l}199 \text { hotels } \\
\text { in the US }\end{array}$ & $\begin{array}{l}561 \\
\text { employees } \\
\text { and } 236 \\
\text { managers }\end{array}$ & $\begin{array}{l}\text { Management } \\
\text { Commitment } \\
\text { to Service } \\
\text { Quality }\end{array}$ & $\begin{array}{l}\text { Empowering } \\
\text { Leadership and } \\
\text { Participative } \\
\text { Leadership } \\
\end{array}$ & $\begin{array}{l}\text { Shared values }(\beta= \\
0.223, \mathrm{p}<0.05) \text { and } \\
\text { Role clarity }(n . s)\end{array}$ & NA & $\begin{array}{l}\text { Employees' } \\
\text { commitment to } \\
\text { service quality }(n . s) \\
\& \\
\text { Job Satisfaction ( } \beta= \\
-0.186, \mathrm{p}<0.05)\end{array}$ & $\begin{array}{l}\text { Path-goal } \\
\text { theory \& } \\
\text { Transformational } \\
\text { theory }\end{array}$ & $\begin{array}{l}\text { Management commitment to service quality } \\
\text { and empowering leadership promote } \\
\text { transformational climate which in turn } \\
\text { enhances shared values and role clarity. }\end{array}$ \\
\hline $\begin{array}{l}\text { Namasivay } \\
\text { am et al. } \\
(2014)\end{array}$ & $\begin{array}{l}\text { Adapted } 16 \\
\text { items from the } \\
\text { scale by } \\
\text { Konczak et al. } \\
(2000)\end{array}$ & Quantitative & $\begin{array}{l}\text { Questionnaire } \\
\text { survey }\end{array}$ & $\begin{array}{l}\text { A medium- } \\
\text { sized family } \\
\text { restaurant } \\
\text { chain in } \\
\text { Northeaster } \\
\text { n US }\end{array}$ & $\begin{array}{l}238 \\
\text { frontline } \\
\text { employees } \\
\text { and } 2,915 \\
\text { customers }\end{array}$ & NA & $\begin{array}{l}\text { Leader } \\
\text { Empowering } \\
\text { Behaviors } \\
\end{array}$ & $\begin{array}{l}\text { Psychological } \\
\text { empowerment }(\beta= \\
0.42, \mathrm{p}<0.01)\end{array}$ & NA & $\begin{array}{l}\text { Employee } \\
\text { satisfaction }(\beta= \\
0.20, \mathrm{p}<0.05)\end{array}$ & $\begin{array}{l}\text { The "linkage } \\
\text { research" framework } \\
\text { (Schneider et al., } \\
\text { 2005) }\end{array}$ & $\begin{array}{l}\text { Empowering leadership predicts } \\
\text { psychological empowerment which in turn } \\
\text { enhances employee satisfaction, } \\
\text { employees' organizational commitment and } \\
\text { customer satisfaction. }\end{array}$ \\
\hline $\begin{array}{l}\text { Lin et al. } \\
(2020)\end{array}$ & $\begin{array}{l}\text { Adapted } 13 \text { of } \\
\text { the } 16 \text { items of }\end{array}$ & Quantitative & $\begin{array}{l}\text { Questionnaire } \\
\text { survey }\end{array}$ & $\begin{array}{l}19 \text { hotels in } \\
\text { in } \\
\text { China }\end{array}$ & $\begin{array}{l}\begin{array}{l}527 \\
\text { employees }\end{array} \\
\end{array}$ & $\mathrm{NA}$ & $\begin{array}{l}\text { Empowering } \\
\text { leadership }\end{array}$ & $\begin{array}{l}\text { Group's relational } \\
\text { conflicts }(\beta=0.27 \\
p<0.05) \& \text { Follower's }\end{array}$ & $\begin{array}{l}\text { Follower's } \\
\text { psychologica } \\
1 \text { safety }\end{array}$ & $\begin{array}{l}\text { Follower's } \\
\text { knowledge hiding }(\beta \\
=-0.17, \mathrm{p}<0.05)\end{array}$ & $\begin{array}{l}\text { Social exchange } \\
\text { theory, social } \\
\text { learning theory, }\end{array}$ & $\begin{array}{l}\text { Differentiated empowering leadership } \\
\text { positively influences employees' } \\
\text { knowledge hiding through group relational }\end{array}$ \\
\hline
\end{tabular}




\begin{tabular}{|c|c|c|c|c|c|c|c|c|c|c|c|c|}
\hline & $\begin{array}{l}\text { Srivastava et } \\
\text { al. (2006) scale }\end{array}$ & & & & & & & $\begin{array}{l}\text { psychological safety }(\beta \\
=0.49, \mathrm{p}<0.01)\end{array}$ & & & $\begin{array}{l}\text { and social } \\
\text { comparison theory }\end{array}$ & $\begin{array}{l}\text { conflict, while individual-focused } \\
\text { empowering leadership negatively } \\
\text { influences their knowledge hiding through } \\
\text { their psychological safety. } \\
\text { Employee's psychological safety moderates } \\
\text { the association between employee's } \\
\text { knowledge hiding and team relational } \\
\text { conflict. }\end{array}$ \\
\hline $\begin{array}{l}\text { Hong et al. } \\
\text { (2016) }\end{array}$ & $\begin{array}{l}\text { 10-item scale } \\
\text { of Vecchio et } \\
\text { al. }(2010)\end{array}$ & Quantitative & $\begin{array}{l}\text { Questionnaire } \\
\text { survey }\end{array}$ & $\begin{array}{l}22 \\
\text { European } \\
\text { hotels }\end{array}$ & $\begin{array}{l}664 \\
\text { employees } \\
\text { and } 260 \\
\text { supervisors } \\
\text { from } \\
160 \\
\text { department } \\
\text { s }\end{array}$ & NA & $\begin{array}{l}\text { Empowering } \\
\text { leadership and } \\
\text { Initiative } \\
\text { enhancing HRM } \\
\text { systems }\end{array}$ & $\begin{array}{l}\text { Initiative climate }(\beta= \\
0.27, \mathrm{p}<0.05), \text { Role } \\
\text { breath self-efficacy } \\
(n . s) \text {, Intrinsic } \\
\text { motivation }(n . s), \\
\text { Activated positive } \\
\text { affect }(n . s)\end{array}$ & $\begin{array}{l}\text { Initiative } \\
\text { enhancing } \\
\text { HRM } \\
\text { systems }\end{array}$ & $\begin{array}{l}\text { Personal initiative } \\
(n . s)\end{array}$ & $\begin{array}{l}\text { Theory of proactive } \\
\text { motivation }\end{array}$ & $\begin{array}{l}\text { Initiative enhancing HRM systems promote } \\
\text { initiative climate, which was associated } \\
\text { with employee's personal initiative via } \\
\text { employee role-breadth self-efficacy. In } \\
\text { addition, empowering leadership promotes } \\
\text { initiative climate only when initiative } \\
\text { enhancing HRM systems were low. }\end{array}$ \\
\hline $\begin{array}{l}\text { Lin et al. } \\
(2019)\end{array}$ & $\begin{array}{l}\text { Arnold et al. } \\
\text { (2000) } 15 \text {-item } \\
\text { scale }\end{array}$ & Quantitative & $\begin{array}{l}\text { Questionnaire } \\
\text { survey }\end{array}$ & $\begin{array}{l}24 \text { Chinese } \\
\text { hotels }\end{array}$ & $\begin{array}{l}558 \\
\text { employees } \\
\text { and } 86 \\
\text { supervisors }\end{array}$ & NA & $\begin{array}{l}\text { Empowering } \\
\text { Leadership of } \\
\text { top-level leaders } \\
\& \text { Self-efficacy } \\
\text { of middle-level } \\
\text { leaders }\end{array}$ & $\begin{array}{l}\text { Middle-level } \\
\text { empowering } \\
\text { leadership }(\beta=0.30, \\
\mathrm{p}<0.01) \& \text { Employee } \\
\text { psychological } \\
\text { ownership }(\beta=0.70, \\
p<0.01)\end{array}$ & $\begin{array}{l}\text { Empowering } \\
\text { leadership of } \\
\text { top-level } \\
\text { leaders }\end{array}$ & $\begin{array}{l}\text { Employee service- } \\
\text { oriented behaviors }(\beta \\
=0.63, \mathrm{p}<0.01 \text { ) }\end{array}$ & $\begin{array}{l}\text { Person- } \\
\text { situation } \\
\text { interactionist theory, } \\
\text { Service profit chain } \\
\text { theory, Motivational } \\
\text { and exchange based } \\
\text { models }\end{array}$ & $\begin{array}{l}\text { Empowering leadership of the top-level } \\
\text { leaders and self-efficacy of the middle-level } \\
\text { leaders influence empowering leadership of } \\
\text { the middle-level leaders. } \\
\text { The association between empowering } \\
\text { leadership at middle-level and service- } \\
\text { oriented behaviors exists and is mediated } \\
\text { by employees' psychological ownership. }\end{array}$ \\
\hline
\end{tabular}

